Prepared in cooperation with the Harris-Galveston Subsidence District, City of Houston, Fort Bend Subsidence District, Lone Star Groundwater Conservation District, and Brazoria County Groundwater Conservation District

\title{
Water-Level Altitudes 2015 and Water-Level Changes in the Chicot, Evangeline, and Jasper Aquifers and Compaction 1973-2014 in the Chicot and Evangeline Aquifers, Houston-Galveston Region, Texas
}

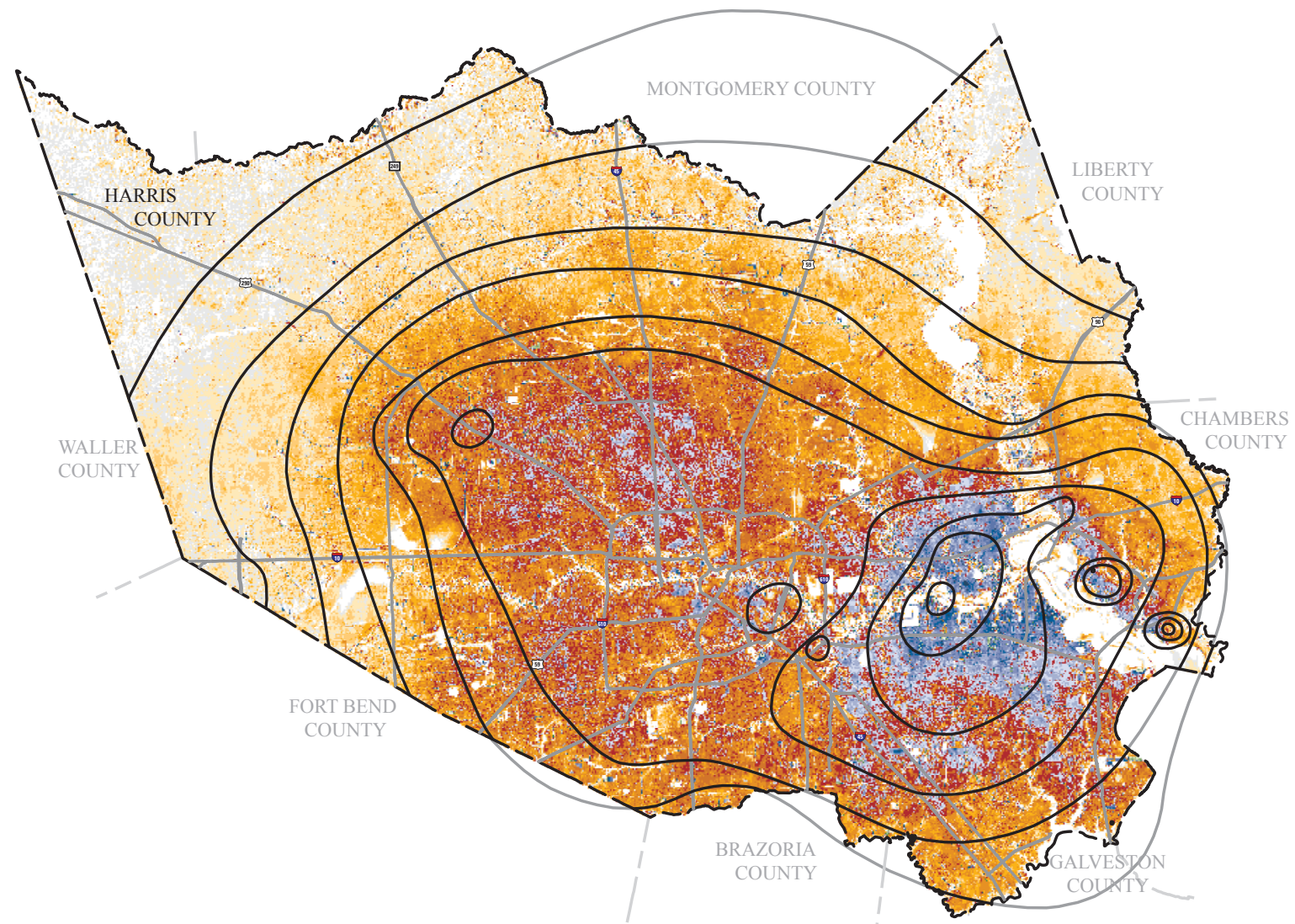

Pamphlet to accompany

Scientific Investigations Map 3337

Version 1.1, October 2015 



\section{Water-Level Altitudes 2015 and Water-Level Changes in the Chicot, Evangeline, and Jasper Aquifers and Compaction 1973-2014 in the Chicot and Evangeline Aquifers, Houston-Galveston Region, Texas}

By Mark C. Kasmarek, Jason K. Ramage, Natalie A. Houston, Michaela R. Johnson, and Tiffany S. Schmidt

Prepared in cooperation with the Harris-Galveston Subsidence District, City of Houston, Fort Bend Subsidence District, Lone Star Groundwater Conservation District, and Brazoria County Groundwater Conservation District

Pamphlet to accompany

Scientific Investigations Map 3337

Version 1.1. October 2015 


\title{
U.S. Department of the Interior SALLY JEWELL, Secretary
}

\section{U.S. Geological Survey Suzette M. Kimball, Acting Director}

\author{
U.S. Geological Survey, Reston, Virginia \\ First release: 2015 \\ Revised: October 2015 (ver. 1.1)
}

For more information on the USGS —-the Federal source for science about the Earth, its natural and living resources, natural hazards, and the environment—visit http://www.usgs.gov or call 1-888-ASK-USGS.

For an overview of USGS information products, including maps, imagery, and publications, visit http://www.usgs.gov/pubprod/.

Any use of trade, firm, or product names is for descriptive purposes only and does not imply endorsement by the U.S. Government.

Although this information product, for the most part, is in the public domain, it also may contain copyrighted materials as noted in the text. Permission to reproduce copyrighted items must be secured from the copyright owner.

Suggested citation:
Kasmarek, M.C.,
and water-level ch
and Evangeline aq
Investigations Map
ISSN 2329-1311 (print)
ISSN 2329-132X (online)
ISBN 978-1-4113-3964-4 


\section{Acknowledgments}

The authors thank the owners and operators of wells throughout the study area for granting access to wells and providing pertinent information that expedited data-collection activities.

Additionally, the authors gratefully acknowledge the assistance of the following U.S.

Geological Survey colleagues for collecting water-level data outside of normal duty hours as necessary and for assisting in processing and analyzing the large amount of resulting data within an abbreviated period: Dexter W. Brown, Joe T. Friez, Tom J. Pistillo, Jody L. Avant, Jimmy E. Hopkins, Chris L. Braun, and Jason D. Payne. 



\section{Contents}

Abstract
Introduction.
Purpose and Scope
Hydrogeology of the Study Area
Subsidence and Compaction Processes Collection and Analysis Methods
Determination of Water-Level Altitudes
Quality Assurance
Depicting Changes in Water-Level Altitudes
Borehole Extensometers
Ehicot Aquifer
Jasper Aquifer

Appendix 1.

[Available at http://dx.doi.org/10.3133/sim3337.]

1-1. Map showing locations of monitoring wells screened in the Chicot aquifer, 2015, Houston-Galveston region, Texas.

1-2. Map showing locations of monitoring wells screened in the Evangeline aquifer, 2015, Houston-Galveston region, Texas.

1-3. Map showing locations of monitoring wells screened in the Jasper aquifer, 2015, Houston-Galveston region, Texas. 


\section{Sheets}

[Available at http://dx.doi.org/10.3133/sim3337.]

1. Map showing approximate $\mathbf{2 0 1 5}$ water-level altitudes in the Chicot aquifer, Houston-Galveston region, Texas.

2. Map showing water-level changes in the Chicot aquifer, Houston-Galveston region, Texas, 2014-15.

3. Map showing approximate water-level changes in the Chicot aquifer, Houston-Galveston region, Texas, 2010-15.

4. Map showing approximate water-level changes in the Chicot aquifer, Houston-Galveston region, Texas, 1990-2015.

5. Map showing approximate water-level changes in the Chicot aquifer, Houston-Galveston region, Texas, 1977-2015.

6. Map showing approximate 2015 water-level altitudes in the Evangeline aquifer, Houston-Galveston region, Texas.

7. Map showing water-level changes in the Evangeline aquifer, Houston-Galveston region, Texas, 2014-15.

8. Map showing approximate water-level changes in the Evangeline aquifer, Houston-Galveston region, Texas, 2010-15.

9. Map showing approximate water-level changes in the Evangeline aquifer, Houston-Galveston region, Texas, 1990-2015.

10. Map showing approximate water-level changes in the Evangeline aquifer, Houston-Galveston region, Texas, 1977-2015.

11. Map showing approximate 2015 water-level altitudes in the Jasper aquifer, Houston-Galveston region, Texas.

12. Map showing water-level changes in the Jasper aquifer, Houston-Galveston region, Texas, 2014-15.

13. Map showing approximate water-level changes in the Jasper aquifer, Houston-Galveston region, Texas, 2010-15.

14. Map showing approximate water-level changes in the Jasper aquifer, Houston-Galveston region, Texas, 2000-15.

15. Map showing locations of borehole-extensometer sites, Houston-Galveston region, Texas, 2014.

16. Graphs showing measured cumulative compaction of subsurface sediments at borehole-extensometer sites depicted on sheet 15, 1973-2014. 


\section{Figures}

1. Map showing locations of groundwater regulatory districts; approximate traces of hydrogeologic sections $A-A^{\prime}, B-B^{\prime}$, and $C-C^{\prime}$; and the Houston-Galveston region study area, Texas, 2015.

2. Hydrogeologic section $A-A^{\prime}$ of the Gulf Coast aquifer system in Grimes, Montgomery, Harris, and Galveston Counties, Texas.

3. Hydrogeologic section $B-B^{\prime}$ of the Gulf Coast aquifer system in Fort Bend County, Texas.

4. Hydrogeologic section $C-C^{\prime}$ of the Gulf Coast aquifer system in Montgomery and Harris Counties, Texas ....

5. Stratigraphic column showing geologic and hydrogeologic units of the Gulf Coast aquifer system in the Houston-Galveston region study area, Texas.

6. Diagram showing mechanism of subsidence caused by potentiometric surface declines induced by groundwater withdrawals in an aquifer composed of gravel, sand, silt, and clay.

7. Diagram showing cross-sectional perspective of the borehole extensometer/piezometer located at Pasadena, Texas.

\section{Tables}

[Available at http://dx.doi.org/10.3133/sim3337.]

1. Data for the Chicot aquifer sheets 1,2,3,4, and 5: (1) approximate 2015 water-level altitudes (water-level-measurement data collected during December 2014-March 2015), (2) water-level changes 2014-15, (3) approximate water-level changes 2010-15, (4) approximate water-level changes 1990-2015, and (5) approximate water-level changes 1977-2015 in the Houston-Galveston region, Texas.

2. Data for the Evangeline aquifer sheets $6,7,8,9$, and 10: (6) approximate 2015 water-level altitudes (water-level-measurement data collected during December 2014-March 2015), (7) water-level changes 2014-15, (8) approximate water-level changes 2010-15, (9) approximate water-level changes 1990-2015, and (10) approximate water-level changes 1977-2015 in the Houston-Galveston region, Texas.

3. Data for the Jasper aquifer sheets $11,12,13$, and 14: (11) approximate 2015 water-level altitudes (water-level-measurement data collected during December 2014-March 2015), (12) water-level changes 2014-15, (13) approximate water-level changes 2010-15, and (14) approximate water-level changes 2000-15 in the Houston-Galveston region, Texas.

4. Data for sheet 16 , measured cumulative compaction of subsurface sediments, 1973-2014, at borehole-extensometer sites depicted on sheet 15, Houston-Galveston region, Texas. 


\section{Conversion Factors}

Inch/Pound to International System of Units

\begin{tabular}{lll}
\hline \multicolumn{1}{c}{ Multiply } & By & \multicolumn{1}{c}{ To obtain } \\
\hline inch (in.) & Length & \\
foot (ft) & 2.54 & centimeter $(\mathrm{cm})$ \\
mile (mi) & 0.3048 & meter $(\mathrm{m})$ \\
\hline & 1.609 & kilometer $(\mathrm{km})$ \\
\hline square mile $\left(\mathrm{mi}^{2}\right)$ & Area & \\
\hline & 2.590 & square kilometer $\left(\mathrm{km}^{2}\right)$ \\
\hline foot squared per day $\left(\mathrm{ft}^{2} / \mathrm{d}\right)$ & Transmissivity* & \\
\hline
\end{tabular}

International System of Units to Inch/Pound

\begin{tabular}{|c|c|c|}
\hline Multiply & By & To obtain \\
\hline \multicolumn{3}{|c|}{ Volume } \\
\hline liter (L) & 33.82 & ounce, fluid (fl. oz) \\
\hline liter $(\mathrm{L})$ & 2.113 & pint $(\mathrm{pt})$ \\
\hline liter $(\mathrm{L})$ & 1.057 & quart (qt) \\
\hline liter $(\mathrm{L})$ & 0.2642 & gallon (gal) \\
\hline liter (L) & 61.02 & cubic inch $\left(\mathrm{in}^{3}\right)$ \\
\hline \multicolumn{3}{|c|}{ Mass } \\
\hline milligram (g) & 0.00003527 & ounce, avoirdupois (oz) \\
\hline
\end{tabular}

Vertical coordinate information is referenced to the National Geodetic Vertical Datum of 1929 (NGVD 29) or the North American Vertical Datum of 1988 (NAVD 88).

Horizontal coordinate information is referenced to the North American Datum of 1927 (NAD 27).

\section{Supplemental Information}

Transmissivity: The standard unit for transmissivity is cubic foot per day per square foot times foot of aquifer thickness [(ft $\left.\left.\mathrm{ft}^{3} / \mathrm{d}\right) / \mathrm{ft}^{2}\right] \mathrm{ft}$. In this report, the mathematically reduced form, foot squared per day $\left(\mathrm{ft}^{2} / \mathrm{d}\right)$, is used for convenience.

Concentrations of chemical constituents in water are given in either milligrams per liter (mg/L) or micrograms per liter ( $\mu \mathrm{g} / \mathrm{L})$. 


\title{
Water-Level Altitudes 2015 and Water-Level Changes in the Chicot, Evangeline, and Jasper Aquifers and Compaction 1973-2014 in the Chicot and Evangeline Aquifers, Houston-Galveston Region, Texas
}

\author{
By Mark C. Kasmarek, Jason K. Ramage, Natalie A. Houston, Michaela R. Johnson, and Tiffany S. Schmidt
}

\section{Abstract}

Most of the land-surface subsidence in the HoustonGalveston region, Texas, has occurred as a direct result of groundwater withdrawals for municipal supply, commercial and industrial use, and irrigation that depressured and dewatered the Chicot and Evangeline aquifers, thereby causing compaction of the aquifer sediments, mostly in the finegrained silt and clay layers. This report, prepared by the U.S. Geological Survey in cooperation with the Harris-Galveston Subsidence District, City of Houston, Fort Bend Subsidence District, Lone Star Groundwater Conservation District, and Brazoria County Groundwater Conservation District, is one in an annual series of reports depicting water-level altitudes and water-level changes in the Chicot, Evangeline, and Jasper aquifers and measured cumulative compaction of subsurface sediments in the Chicot and Evangeline aquifers in the Houston-Galveston region. The report contains regionalscale maps depicting approximate 2015 water-level altitudes (represented by measurements made during December 2014March 2015) for the Chicot, Evangeline, and Jasper aquifers; maps depicting 1-year (2014-15) water-level changes for each aquifer; maps depicting approximate contoured 5-year (201015) water-level changes for each aquifer; maps depicting approximate contoured long-term (1990-2015 and 19772015) water-level changes for the Chicot and Evangeline aquifers; a map depicting approximate contoured long-term (2000-15) water-level changes for the Jasper aquifer; a map depicting locations of borehole-extensometer sites; and graphs depicting measured cumulative compaction of subsurface sediments at the borehole extensometers during 1973-2014. Three tables listing the water-level data used to construct each water-level map for each aquifer and a table listing the measured cumulative compaction data for each extensometer site and graphs are included.

In 2015, water-level-altitude contours for the Chicot aquifer ranged from 175 feet (ft) below the vertical datum (the National Geodetic Vertical Datum of 1929 or the North American Vertical Datum of 1988; hereinafter, datum) in a localized area in northwestern Harris County to $200 \mathrm{ft}$ above datum in northern and western Montgomery County. Waterlevel changes for 2014-15 in the Chicot aquifer ranged from a $24-\mathrm{ft}$ decline to a $31-\mathrm{ft}$ rise. Contoured 5-year and long-term water-level changes in the Chicot aquifer ranged from a $40-\mathrm{ft}$ decline to a 40-ft rise (2010-15), from a 100-ft decline to a $100-\mathrm{ft}$ rise (1990-2015), and from a 100-ft decline to a $200-\mathrm{ft}$ rise (1977-2015). In 2015, water-level-altitude contours for the Evangeline aquifer ranged from $250 \mathrm{ft}$ below datum in a localized area extending from south-central Montgomery County into north-central Harris County and in an additional area located in central Harris County to $200 \mathrm{ft}$ above datum in southeastern Grimes and northwestern Montgomery Counties. Water-level changes for 2014-15 in the Evangeline aquifer ranged from a $66-\mathrm{ft}$ decline to a 78 -ft rise. Contoured 5-year and long-term water-level changes in the Evangeline aquifer ranged from a 60 - $\mathrm{ft}$ decline to an 80-ft rise (2010-15), from a $200-\mathrm{ft}$ decline to a $240-\mathrm{ft}$ rise (1990-2015), and from a $320-\mathrm{ft}$ decline to a 240-ft rise (1977-2015). In 2015, water-levelaltitude contours for the Jasper aquifer ranged from $200 \mathrm{ft}$ below datum in south-central Montgomery County that extends into north-central Harris County to $250 \mathrm{ft}$ above datum in northwestern Montgomery County. Water-level changes for 2014-15 in the Jasper aquifer ranged from a 17-ft decline to a 35 -ft rise. Contoured 5-year and long-term water-level changes in the Jasper aquifer ranged from a 60-ft decline to four small, localized areas of 10-ft rises (2010-15) and from a 220-ft decline to no change (2000-15).

Compaction of subsurface sediments (mostly in the fine-grained silt and clay layers) composing the Chicot and Evangeline aquifers was recorded continuously by using analog technology at the 13 borehole extensometers at 11 sites that were either activated or installed between 1973 and 1980. For the period of record beginning in 1973 (or later depending on activation or installation date) and ending in December 2014, 
measured cumulative compaction at the 13 extensometers ranged from $0.101 \mathrm{ft}$ at the Texas City-Moses Lake extensometer to $3.668 \mathrm{ft}$ at the Addicks extensometer. During 2014, a total of 10 of the 13 extensometers recorded a slight net decrease of land-surface elevation; the extensometers at the Lake Houston and Clear Lake (shallow) sites recorded slight net increases of land-surface elevation, and the extensometer at the Texas City-Moses Lake site recorded no change in elevation. The rate of compaction varies from site to site because of differences in rates of groundwater withdrawal in the areas adjacent to each extensometer site and differences among sites in the ratios of sand, silt, and clay and compressibilities of the subsurface sediments. It is not appropriate, therefore, to extrapolate or infer a rate of compaction for an adjacent area on the basis of the rate of compaction measured at nearby extensometers.

\section{Introduction}

Allen (1969) described ground-surface displacement as the last step of a variety of subsurface displacement mechanisms that included (among others) compaction of subsurface sediments by loading, drainage, vibration, and hydrocompaction. The Houston-Galveston region, Texasconsisting of Harris, Galveston, Fort Bend, Montgomery, Brazoria, Chambers, Grimes, Liberty, San Jacinto, Walker, and Waller Counties (fig. 1) - represents one of the largest areas of ground-surface displacement (also called land-surface subsidence and hereinafter referred to as "subsidence") in the United States (Coplin and Galloway, 1999). According to Coplin and Galloway (1999, p. 40), by 1979, as much as 10 feet ( $\mathrm{ft}$ ) of subsidence had occurred in the HoustonGalveston region, and approximately 3,200 square miles $\left(\mathrm{mi}^{2}\right)$ of the $11,000-\mathrm{mi}^{2}$ geographic area had subsided more than $1 \mathrm{ft}$. Comparing land-surface altitudes for $1915-17$ to those for 2001, Kasmarek, Gabrysch, and Johnson (2010, sheet 2) determined that as much as $13 \mathrm{ft}$ of subsidence in a small, localized area had occurred in southeastern Harris County during the historical period. This report, prepared by the U.S. Geological Survey in cooperation with the Harris-Galveston Subsidence District, City of Houston, Fort Bend Subsidence District, Lone Star Groundwater Conservation District, and Brazoria County Groundwater Conservation District, is one in an annual series of reports depicting water-level altitudes and water-level changes in the Chicot, Evangeline, and Jasper aquifers and measured cumulative compaction of fine-grained subsurface sediments in the Chicot and Evangeline aquifers in the Houston-Galveston region.

Subsidence has been linked to hydrocarbon extraction and groundwater withdrawals in the Houston-Galveston region. Subsidence caused by hydrocarbon extraction was first documented in the Houston-Galveston region in 1926, at the Goose Creek Oil Field in southeastern Harris County (fig. 1) (Pratt and Johnson, 1926). Although subsidence was first identified in the Houston-Galveston region as a result of hydrocarbon extraction at this particular oil field, most of the subsidence in the Houston-Galveston region is a direct result of groundwater withdrawals that have depressured and dewatered the Chicot and Evangeline aquifers, thereby causing compaction of the aquifer sediments (Winslow and Doyel, 1954; Winslow and Wood, 1959; Gabrysch and Bonnet, 1975; Gabrysch, 1984; Holzer and Bluntzer, 1984; Kasmarek, Gabrysch, and Johnson, 2010).

Groundwater withdrawn from the Chicot, Evangeline, and Jasper aquifers has been the primary source of water for municipal supply, commercial and industrial use, and irrigation in the Houston-Galveston region since the early 1900s (Kasmarek and Robinson, 2004). Prior to 1975, the withdrawal of groundwater from the Chicot and Evangeline aquifers was unregulated, and water levels in the aquifers were declining with associated depressuring, dewatering, and compaction resulting in subsidence (Coplin and Galloway, 1999). By 1977, the withdrawals had resulted in water-levelaltitude declines of 300 and $350 \mathrm{ft}$ below datum in the Chicot and Evangeline aquifers, respectively, in southeastern Harris County (Gabrysch, 1979), and correspondingly, by 1979, as much as $10 \mathrm{ft}$ of subsidence had occurred in the HoustonGalveston region (Coplin and Galloway, 1999).

Subsidence is of particular concern in low-lying coastal areas such as the Houston-Galveston region. Subsidence in the region has increased the frequency and severity of flooding (Coplin and Galloway, 1999). Low-pressure weather systems such as tropical storms and hurricanes result in high rates of precipitation and cause high tides to reach farther inland. Storm surge is an abnormal rise of water generated by a storm, over and above the normal astronomical tides (National Weather Service, 2001; National Oceanic and Atmospheric Administration, 2015a). Subsidence exacerbates the effects of storm surge and impedes stormwater runoff by creating areas of decreased land-surface elevations where water accumulates. Subsidence has shifted the shoreline along Galveston Bay (fig. 1) as evidenced by the inundation of the Brownwood Subdivision (fig. 1) in 1983 near Baytown, Tex., and adjacent areas in the Houston-Galveston region, thereby changing the distribution of wetlands and aquatic vegetation (Coplin and Galloway, 1999).

To address the issues associated with subsidence and subsequent increased flooding, the 64th Texas State Legislature in 1975 authorized the establishment of the Harris-Galveston Subsidence District (HGSD) (fig. 1) to regulate and reduce groundwater withdrawals in Harris and Galveston Counties (Harris-Galveston Subsidence District, 2013). In cooperation with the HGSD, the U.S. Geological Survey (USGS) has monitored water levels in wells screened in the Chicot and Evangeline aquifers and compaction of subsurface sediments in Harris and Galveston Counties since 1976. The USGS has published annual reports depicting water-level altitudes and water-level changes for the Chicot and Evangeline aquifers in the Houston-Galveston region beginning with the 1977 water-level-altitude maps (Gabrysch, 


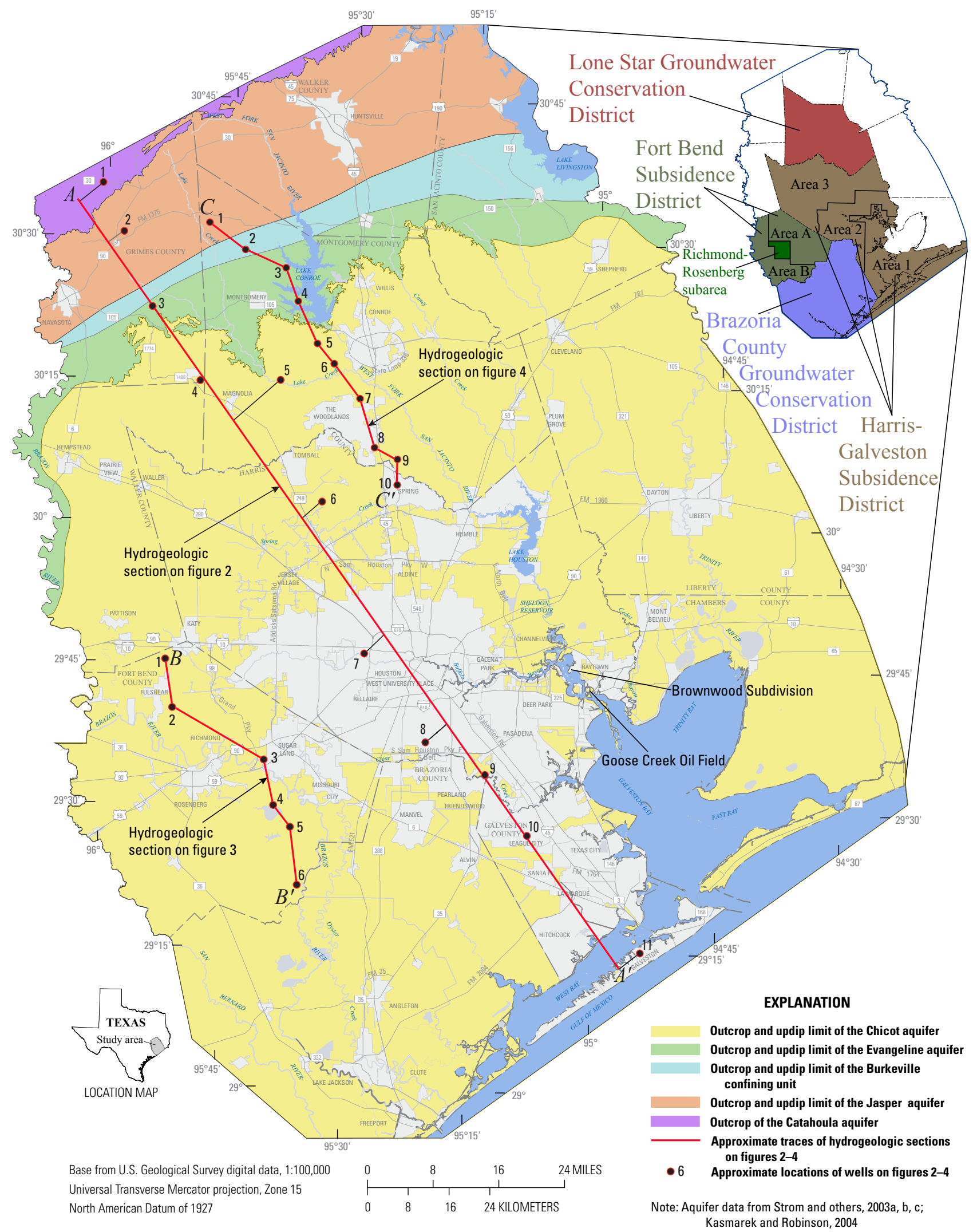

Figure 1. Locations of groundwater regulatory districts; approximate traces of hydrogeologic sections $A-A^{\prime}, B-B^{\prime}$, and $C-C^{\prime}$; and the Houston-Galveston region study area, Texas, 2015 (modified from Strom and others, 2003a, b, c; Kasmarek and Robinson, 2004). 
Water-Level Altitudes 2015 and Water-Level Changes and Compaction 1973-2014, Houston-Galveston Region, Texas

1979). Subsequently, the monitoring of groundwater levels was expanded into the Fort Bend subregion (encompassing Fort Bend County and adjacent areas), and the first waterlevel-altitude maps for this area were created and presented in the 1991 water-level report (Barbie and others, 1991) and subsequently revised in 1997 (Kasmarek, 1997). The USGS published its first annual reports of water-level altitudes and water-level changes for the Jasper aquifer (Coplin, 2001) in the Houston-Galveston region (primarily Montgomery County) beginning in 2000, and after more extensive data were available, an updated report was published (Kasmarek and Houston, 2007). The measured cumulative compaction (hereinafter referred to as "cumulative compaction") data from a network of 13 borehole extensometers (hereinafter referred to as "extensometers") in the Houston-Galveston region have been presented in USGS reports of annual water-level altitudes and water-level changes since 1981 (cumulative compaction during 1973-81; Gabrysch and Ranzau, 1981). Earlier USGS reports documented the occurrence of subsidence in the study area determined by the reoccupation and releveling of a network of benchmarks by using spirit-leveling techniques for the periods 1906-51 (Winslow and Doyel, 1954), 1906-78, 1943-78, and 1973-78 (Gabrysch, 1984). Most recently, Kasmarek and others (2014) depicted 2014 waterlevel altitudes and water-level changes for various periods in the Chicot, Evangeline, and Jasper aquifers and cumulative compaction measured by the extensometers during 1973-2013 in the Chicot and Evangeline aquifers.

Subsequent to establishing the HGSD, the Texas State Legislature established an additional subsidence district (Fort Bend Subsidence District [FBSD]) and two groundwater conservation districts (Lone Star Groundwater Conservation District [LSGCD] and, most recently, Brazoria County Groundwater Conservation District [BCGCD]) in the Houston-Galveston region to provide for the regulation of groundwater withdrawals in areas within their jurisdiction. The FBSD was established by the 71st Texas State Legislature in 1989 and has jurisdiction throughout Fort Bend County (fig. 1). The FBSD is divided into area A, which includes the Richmond-Rosenberg subarea, and area B. The primary purpose of the FBSD is to regulate groundwater withdrawal to prevent subsidence that contributes to flooding (Fort Bend Subsidence District, 2013). The LSGCD was established by the 77th Texas State Legislature in 2001 and has jurisdiction throughout Montgomery County (fig. 1). The purpose of the LSGCD is to conserve, protect, and enhance the groundwater resources of Montgomery County (Lone Star Groundwater Conservation District, 2013). The BCGCD was established by the 78th Texas State Legislature in 2003 with the purpose to maintain the quality and availability of Brazoria County's groundwater resources for current users and future generations (Brazoria County Groundwater Conservation District, 2012). Regulatory plans to gradually decrease groundwater withdrawals by increased usage of alternative surface-water supplies are being phased in; the historical, current (2015), and future groundwater management plans of each district are available on their respective Web sites (Harris-Galveston Subsidence District, 2013; Fort Bend Subsidence District, 2013; Lone Star Groundwater Conservation District, 2013; Brazoria County Groundwater Conservation District, 2012). Currently (2015), groundwater withdrawals are not being regulated by a groundwater conservation district in Liberty and Chambers Counties.

In 1976, the HGSD began implementing its first groundwater regulatory plan (Harris-Galveston Subsidence District, 2013). An extensive well-monitoring network was established by 1977, and water-level data were collected and used to create the first published water-level-altitude maps of the Chicot and Evangeline aquifers in the Houston-Galveston area (Gabrysch, 1979). The FBSD adopted its groundwater management plan in 1990 (Fort Bend Subsidence District, 2013), and in cooperation with the FBSD, an increased number of wells were inventoried by the USGS in Fort Bend, Harris, Brazoria, and Waller Counties in 1989 and 1990. A more comprehensive water-level-altitude report for the Chicot and Evangeline aquifers was published by the USGS in 1991 (Barbie and others, 1991), and when updated well data became available, that water-level-altitude report was revised in 1997 (Kasmarek, 1997). Similarly, after the establishment of the LSGCD in 2001, the USGS first published a water-levelaltitude map of the Jasper aquifer in the Houston-Galveston region (primarily Montgomery County) (Coplin, 2001). In 2004, 2006, and 2007, as additional wells with reliable water-level data were inventoried, revised water-level-altitude maps for the Jasper aquifer were prepared (Kasmarek and Lanning-Rush, 2004; Kasmarek and others, 2006; Kasmarek and Houston, 2007). In comparison to the 2001 (Coplin, 2001) and 2004 (Kasmarek and Lanning-Rush, 2004) reports, the 2007 water-level-altitude map (Kasmarek and Houston, 2007) was the most comprehensive for the Jasper aquifer in the study area prepared at that time. Since 2007, similarly comprehensive maps for the Jasper aquifer have been included in the annual series of reports that depict water-level altitudes and water-level changes in the Chicot, Evangeline, and Jasper aquifers and cumulative compaction in the Chicot and Evangeline aquifers in the Houston-Galveston region (Kasmarek and Houston, 2008; Kasmarek and others, 2009, 2012, 2013, 2014; Kasmarek, Johnson, and Ramage, 2010; Johnson and others, 2011).

\section{Purpose and Scope}

This report is one in an annual series of reports depicting water-level altitudes and water-level changes in the Chicot, Evangeline, and Jasper aquifers and cumulative compaction in the Chicot and Evangeline aquifers in the Houston-Galveston region. The report also describes the hydrogeology of the study area and provides an overview of the mechanism of compaction and subsidence.

This report contains regional-scale maps (sheets 1-14) depicting approximate 2015 water-level altitudes in the 
Chicot, Evangeline, and Jasper aquifers (sheets 1, 6, and 11); maps depicting 1-year (2014-15) water-level changes for each aquifer (sheets 2, 7, and 12); maps depicting approximate contoured 5-year (2010-15) water-level changes for each aquifer (sheets 3, 8, and 13); maps depicting approximate contoured long-term (1990-2015 and 1977-2015) water-level changes for the Chicot and Evangeline aquifers (sheets 4, 5, 9, and 10); and a map depicting approximate contoured longterm (2000-15) water-level changes for the Jasper aquifer (sheet 14).

The point and contour data depicted on the maps for all three aquifers (Chicot, Evangeline, and Jasper) are available for download at http://dx.doi.org/10.3133/sim3337, as are the metadata compliant with Federal Geographic Data Committee-mandated guidelines (Federal Geographic Data Committee, 2015).

In addition to maps depicting water-level altitudes and changes in the Chicot, Evangeline, and Jasper aquifers, this report also contains a map that depicts the locations of the 11 extensometer sites in Harris and Galveston Counties activated or installed between 1973 and 1980 (sheet 15). At these sites, 13 extensometers continuously record cumulative compaction of subsurface sediments of the Chicot and Evangeline aquifers. Graphs of these data from the 13 extensometers from 1973 (or later depending on activation or installation date) through 2014 are provided on sheet 16 .

Tables 1-3 present the water-level data used to construct each water-level map for each aquifer, and table 4 presents the data that support the graphs of measured cumulative compaction of subsurface sediments. Also included is a brief description of the methods used for map construction.

\section{Hydrogeology of the Study Area}

The three primary aquifers in the Gulf Coast aquifer system are the Chicot, Evangeline, and Jasper (figs. 2-4), which are composed of laterally discontinuous deposits of gravel, sand, silt, and clay. The youngest and uppermost aquifer, the Chicot aquifer, consists of Holocene- and Pleistocene-age sediments; the underlying Evangeline aquifer consists of Pliocene- and Miocene-age sediments; and the oldest and most deeply buried aquifer, the Jasper aquifer, consists of Miocene-age sediments (fig. 2) (Baker, 1979, 1986). The lowermost unit of the Gulf Coast aquifer system is the Miocene-age Catahoula confining system, which includes the Catahoula Sandstone. The Catahoula confining system consists of sands in the upper section and clay and tuff interbedded with sand in the lower section (figs. 2 and 4).

Since about 1932, numerous authors have contributed to the body of knowledge and understanding of the complex stratigraphic and hydrogeologic relations of the Gulf Coast aquifer system in the Houston-Galveston study area (fig. 5). Using this information, a series of groundwater flow models have been created, the most recent being Kasmarek (2013); these models provide an evaluative tool that can be used by water-resource managers to help regulate and conserve this important natural-water resource of the aquifer system.

The percentage of clay and other fine-grained clastic material generally increases with depth downdip (Baker, 1979). Through time, geologic and hydrologic processes created accretionary sediment wedges (stacked sequences of sediments) more than 7,600 ft thick at the coast (fig. 2) (Chowdhury and Turco, 2006). The sediments composing the Gulf Coast aquifer system were deposited by fluvial-deltaic processes and subsequently were eroded and redeposited (reworked) by worldwide episodic changes in sea level (eustacy) that occurred as a result of oscillations between glacial and interglacial climate conditions (Lambeck and others, 2002). The Gulf Coast aquifer system consists of hydrogeologic units that dip and thicken from northwest to southeast (fig. 2); the aquifers thus crop out in bands inland from and approximately parallel to the coast and become progressively more deeply buried and confined toward the coast (Kasmarek, 2013, figs. 4-7). The Burkeville confining unit is stratigraphically positioned between the Evangeline and Jasper aquifers (figs. 2-4), thereby restricting groundwater flow between the Evangeline and Jasper aquifers. There is no confining unit between the Chicot and Evangeline aquifers; therefore, the aquifers are hydraulically connected, which allows groundwater flow between the aquifers (fig. 2). Because of this hydraulic connection, water-level changes that occur in one aquifer can affect water levels in the adjoining aquifer (Kasmarek and Robinson, 2004). Supporting evidence of the interaction of groundwater flow between the Chicot and Evangeline aquifers is demonstrated by comparing the two long-term (1977-2014) water-level-change maps (Kasmarek and others, 2014, sheets 5 and 10, respectively) that indicate that the areas where water levels have risen or declined are approximately spatially coincident. Hydraulic properties of the Chicot aquifer do not differ appreciably from the hydrogeologically similar Evangeline aquifer but can be differentiated on the basis of hydraulic conductivity (Carr and others, 1985, p. 10). From aquifer-test data, Meyer and Carr (1979) estimated that the transmissivity of the Chicot aquifer ranges from 3,000 to 25,000 feet squared per day $\left(\mathrm{ft}^{2} / \mathrm{d}\right)$ and that the transmissivity of the Evangeline aquifer ranges from 3,000 to $15,000 \mathrm{ft}^{2} / \mathrm{d}$. The Chicot aquifer outcrops and extends inland from the Gulf Coast and terminates at the most northern updip limit of the aquifer. Proceeding updip and inland of the Chicot aquifer, the older hydrogeologic units of the Evangeline aquifer, the Burkeville confining unit, and the Jasper aquifer sequentially outcrop (fig. 1). In the updip and outcrop areas of the Jasper aquifer, the aquifer can be differentiated from the Evangeline aquifer on the basis of the depths to water below land surface, which are shallower (closer to land surface) in the Jasper aquifer compared to those in the Evangeline aquifer. Additionally, in the downdip parts of the aquifer system, the Jasper aquifer can be differentiated from the Evangeline aquifer on the basis of stratigraphic position relative to the elevation of the Burkeville confining unit (figs. 2-4). 


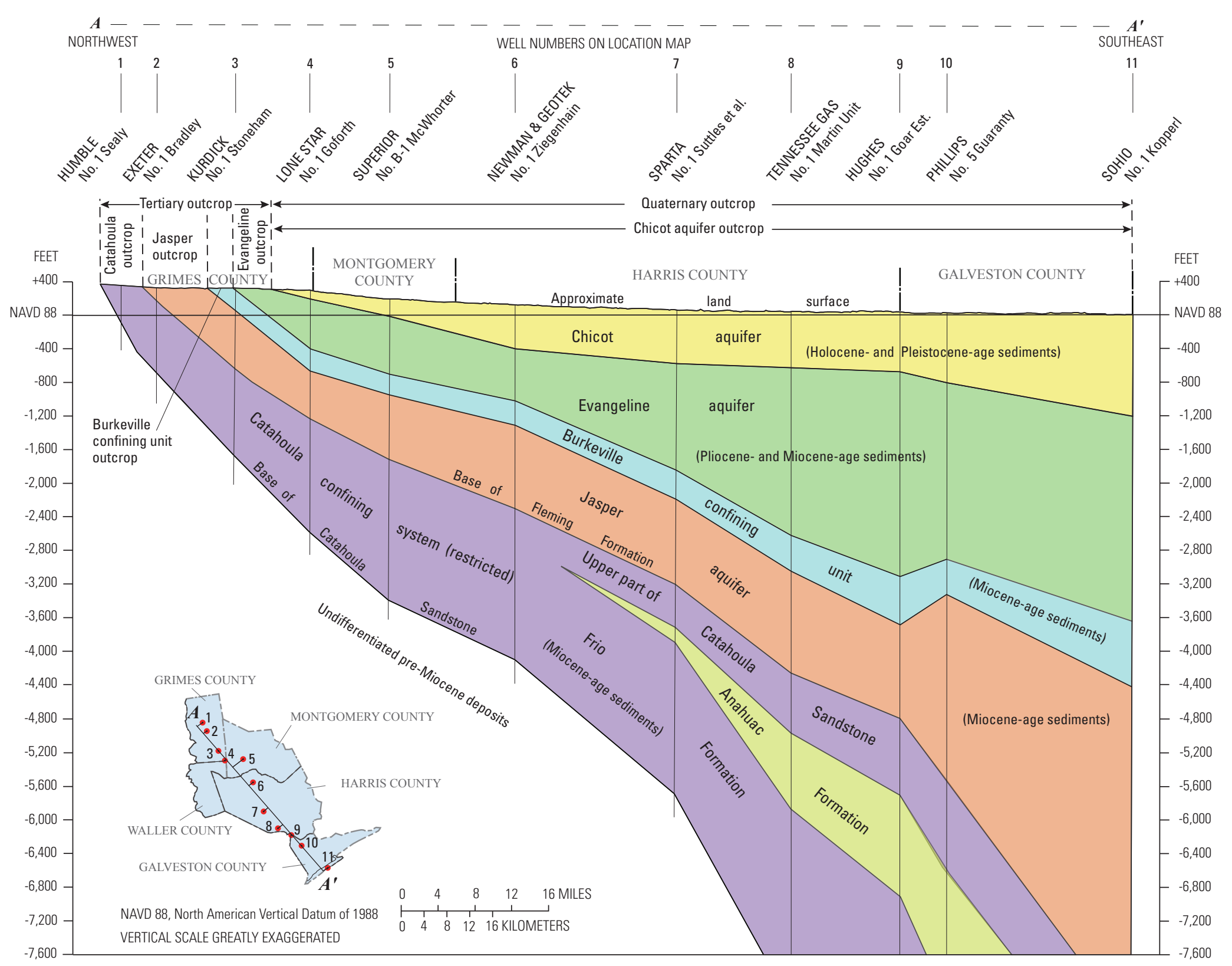

Figure 2. Hydrogeologic section $A-A^{\prime}$ of the Gulf Coast aquifer system in Grimes, Montgomery, Harris, and Galveston Counties, Texas (modified from Baker, 1979, fig. 4). 


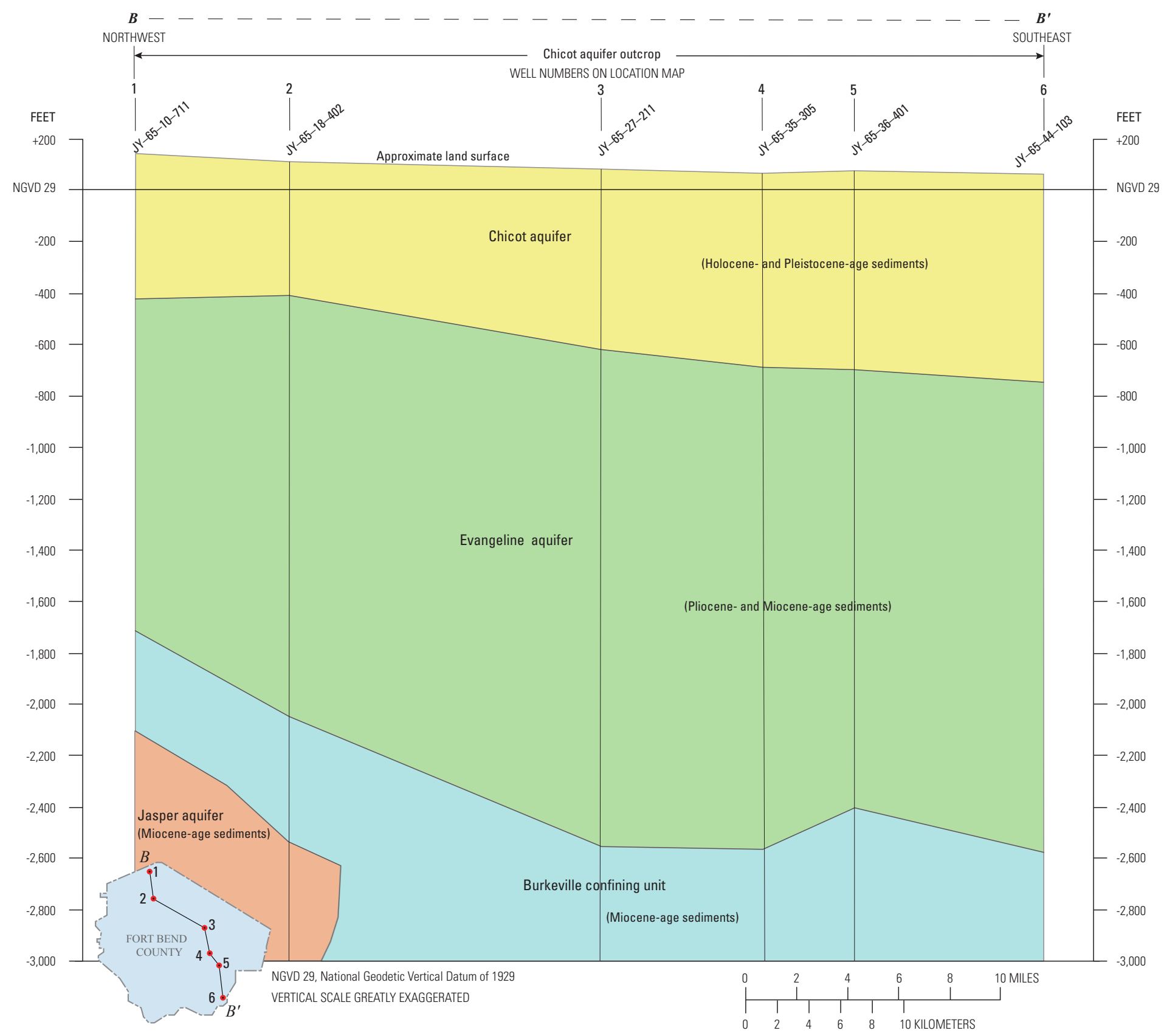

Figure 3. Hydrogeologic section $B-B^{\prime}$ of the Gulf Coast aquifer system in Fort Bend County, Texas (modified from Wesselman, 1972, fig. 30). 


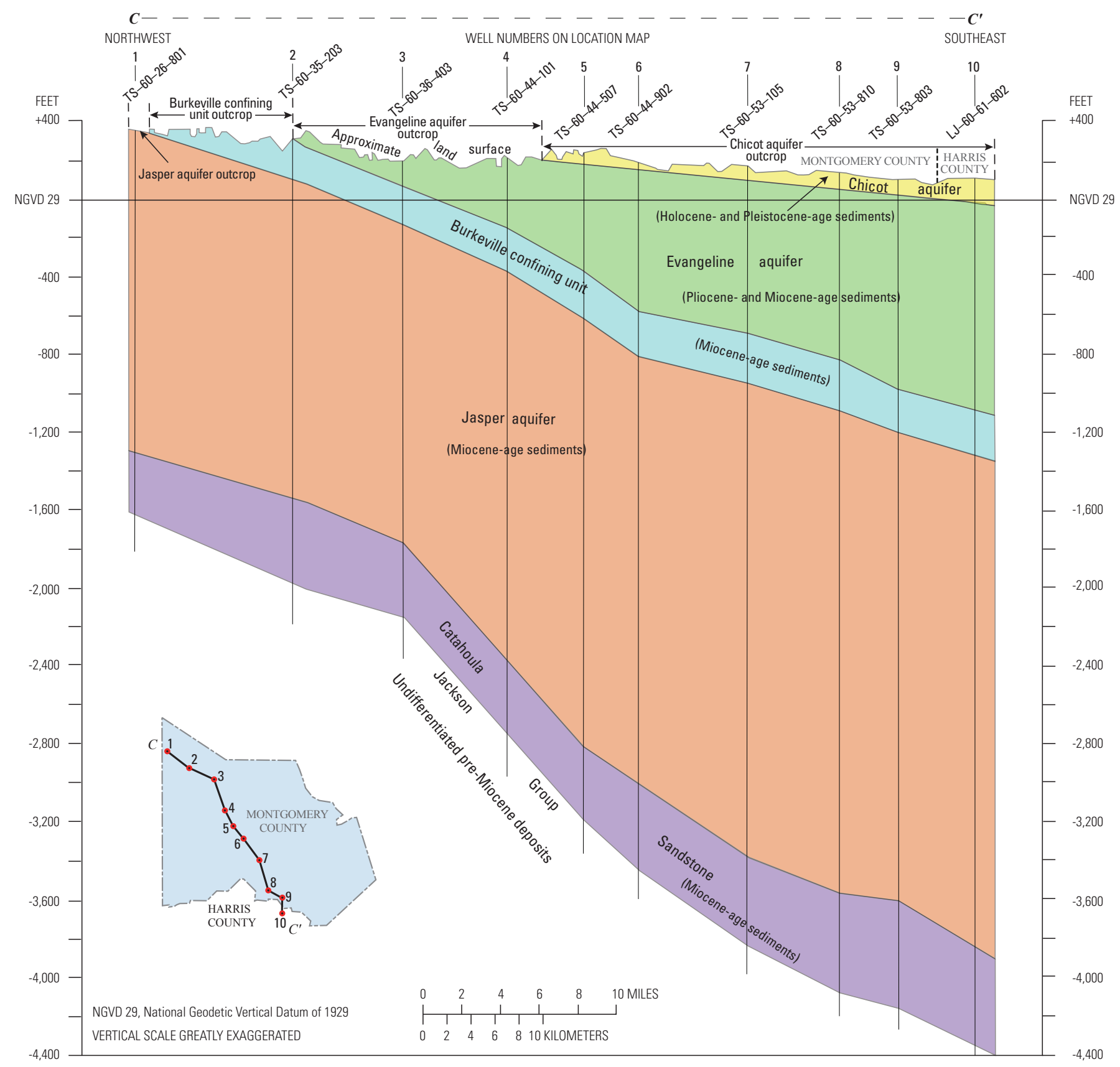

Figure 4. Hydrogeologic section $C-C^{\prime}$ of the Gulf Coast aquifer system in Montgomery and Harris Counties, Texas (modified from Popkin, 1971, fig. 29). 


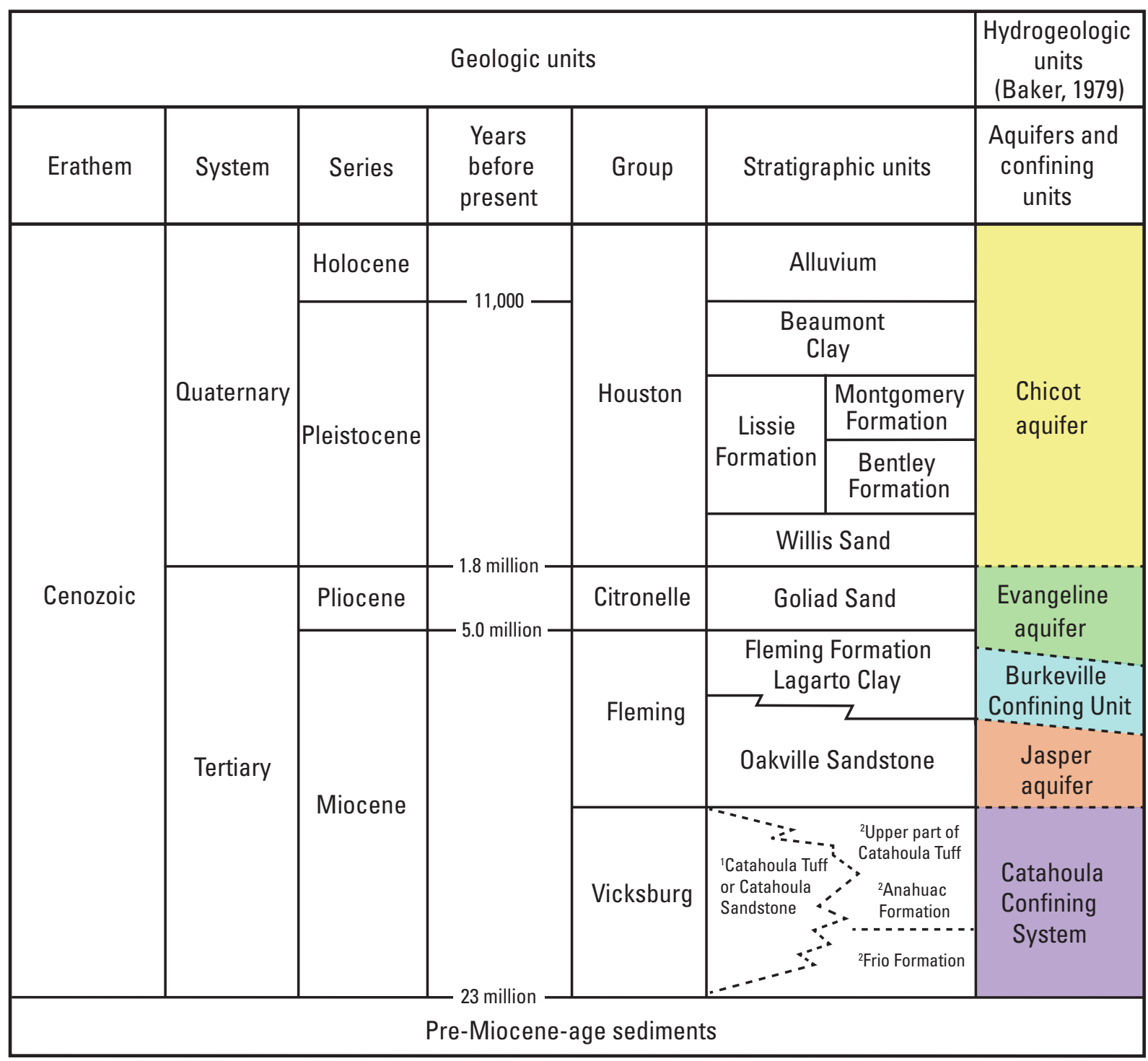

'Located in the outcrop. Located in the subcrop.

Figure 5. Geologic and hydrogeologic units of the Gulf Coast aquifer system in the Houston-Galveston region study area, Texas (modified from Baker, 1979; Meyer and Carr, 1979; and Sellards and others, 1932).

The hydrogeologic cross section $A-A^{\prime}$ (fig. 2) extends through the Houston-Galveston region from northwestern Grimes County, continues southeastward through Montgomery and Harris Counties, terminates at the coast in Galveston County, and depicts the three aquifers thickening and dipping toward the coast from their updip (outcrop) limits. Comparisons of cross sections $A-A^{\prime}$ (fig. 2), $B-B^{\prime}$ (fig. 3), and $C-C^{\prime}$ (fig. 4) indicate that the thicknesses of the three aquifers similarly increase downdip towards the coast. Conversely, in central Harris, southern Montgomery, and Grimes Counties, the sediments of the updip Chicot and Evangeline aquifers become progressively thinner (fig. 2), and in northern Montgomery and Grimes County, the thickness of the sediments composing the Chicot aquifer is effectively insufficient for groundwater withdrawal (fig. 2). The hydrogeologic cross section $C-C^{\prime}$ (fig.
4) extends through Montgomery County into extreme northern Harris County and similarly indicates that sediment thickness of the aquifers progressively decreases towards the northwest updip limit.

The water quality of the Chicot, Evangeline, and Jasper aquifers in the Houston-Galveston region varies spatially and with the depth. For the most part, the groundwater is classified as fresh (less than 1,000 milligrams per liter $[\mathrm{mg} / \mathrm{L}]$ dissolved-solids concentration [Freeze and Cherry, 1979]). Concentrations of dissolved solids range from less than $500 \mathrm{mg} / \mathrm{L}$ in the updip parts of the aquifers to more than $10,000 \mathrm{mg} / \mathrm{L}$ in the downdip and more deeply buried confined parts of the aquifers near the coast (Baker, 1979; Peter and others, 2011). Precipitation falling on the land surface overlying these aquifers returns to the atmosphere 
as evapotranspiration, discharges to streams, or infiltrates as groundwater recharge to the unconfined updip sediments composing the aquifers. The infiltrating water moves downgradient, reaching the intermediate and deep zones of the aquifers southeastward of the outcrop areas; regionally, the recharged water also moves downgradient toward the coast into the intermediate and deep zones of the aquifers, where it can be withdrawn and discharged by wells or is naturally discharged by diffuse upward leakage in topographically low areas near the coast (Kasmarek and Robinson, 2004). Water in the coastal, deep zones of the aquifers is denser, and this higher density water causes the fresher, lower density water that has not been captured and withdrawn by wells to be redirected as diffuse upward leakage to shallow zones of the confined downdip areas of the aquifer system. This water is ultimately discharged along the coast to brackish (dissolvedsolids concentrations of 1,000-10,000 mg/L [Freeze and Cherry, 1979]) water of the coastal bays and estuaries (Kasmarek and Robinson, 2004).

\section{Subsidence and Compaction Processes}

By 1979, as much as $10 \mathrm{ft}$ of subsidence had occurred in the Houston-Galveston region, and approximately 3,200 $\mathrm{mi}^{2}$ of the 11,000-mi ${ }^{2}$ geographic area had subsided more than $1 \mathrm{ft}$ (Coplin and Galloway, 1999). Subsidence can occur as a result of potentiometric surface declines in unconsolidated confined aquifers (Galloway and others, 1999). Potentiometric surface declines cause a decrease in hydraulic pressure (depressuring) that creates a load on the skeletal matrix of the sediments in the aquifer and adjacent confining units (fig. 6). Because sand layers are more transmissive and less compressible than are fine-grained silt and clay layers, sand layers depressure more rapidly compared to silt and clay layers. In addition, when groundwater withdrawals are decreased, pressure equilibrium is reestablished more rapidly in the sand layers compared to the silt and clay layers, and the amount of compaction of the sand layers is usually minor compared to the amount of compaction

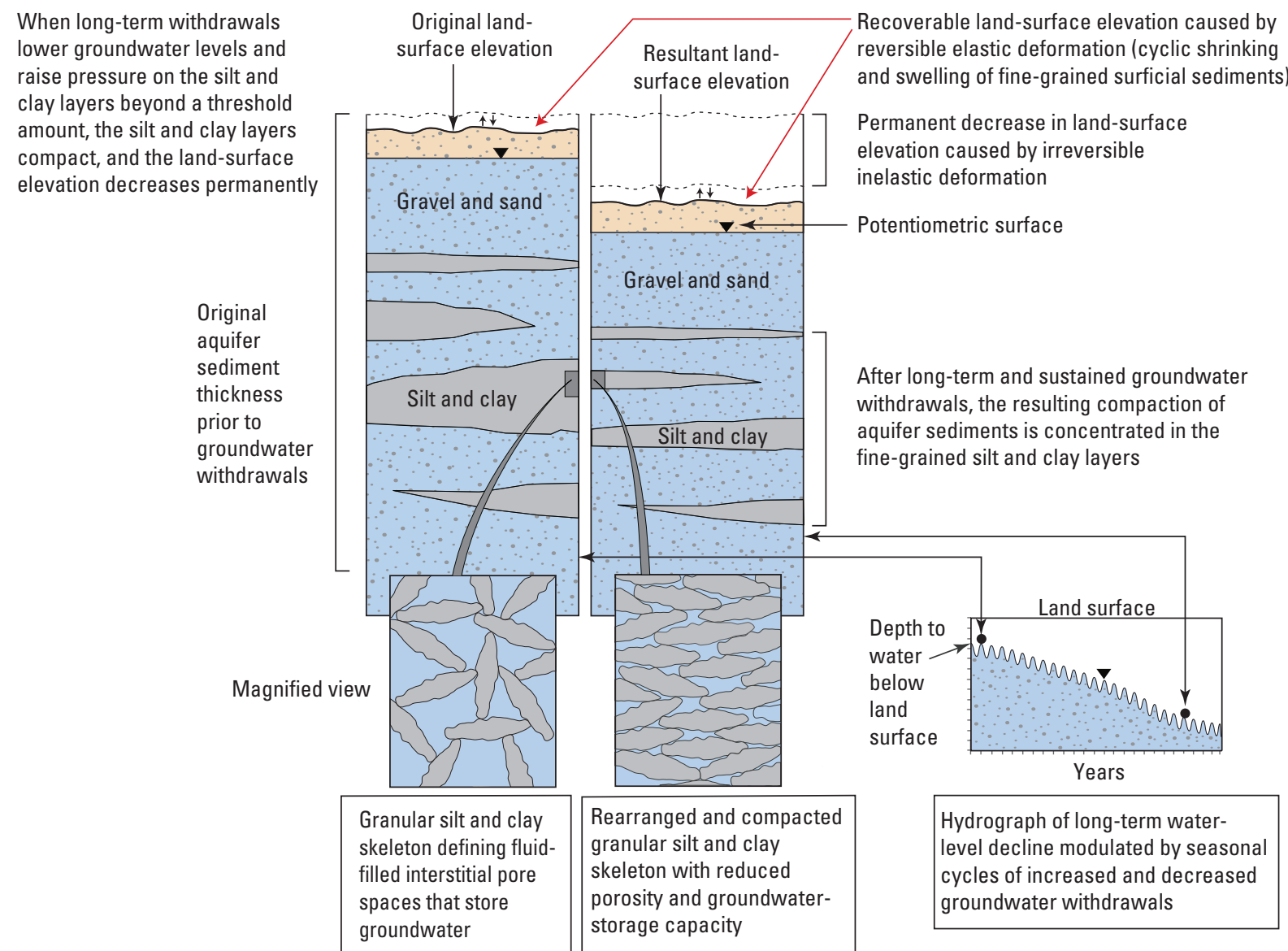

Figure 6. Mechanism of subsidence caused by potentiometric surface declines induced by groundwater withdrawals in an aquifer composed of gravel, sand, silt, and clay (modified from Galloway and others, 1999, p. 9). 
of the silt and clay layers (Trahan, 1982; Galloway and others, 1999). The silt and clay layers are often interbedded within the sand layers, and when depressuring occurs, the silt and clay layers dewater more slowly compared to the sand layers. The compressibility of the silt and clay layers is dependent on the thickness and hydraulic characteristics of the silt and clay layers and the vertical stress of the saturated and unsaturated sediment overburden. Slow drainage of the silt and clay layers continues to occur until the excess residual pore pressure in the silt and clay layers equilibrates with the pore pressure of the adjacent sand layers. As dewatering progresses, compaction of the silt and clay layers continues until hydraulic pressure equilibrium is attained. A similar loading process can occur in sand layers; however, the major difference is that the individual silt and clay grains spatially rearrange as depressuring and dewatering progress, finally becoming perpendicular to the applied vertical overburden load (Galloway and others, 1999). Essentially, the water stored in the silt and clay layers prior to depressuring provides interstitial pore-space support to the skeletal matrix of the silt and clay grains. As water levels continue to decline, the silt and clay layers continue to dewater, depressure, and compact. Additionally, compaction of the silt and clay layers reduces the porosity and groundwater-storage capacity of the silt and clay layers (fig. 6). Because most compaction of subsurface sediments is inelastic, with about 90 percent of the compaction considered permanent, only a small amount of rebound of the land-surface elevation can occur (Gabrysch and Bonnet, 1975). Although the compaction of one thin silt and clay layer generally will not cause a measureable decrease in the land-surface elevation, when numerous stratigraphic sequences of sand layers and silt and clay layers (characteristic of the Gulf Coast aquifer system) depressure and compact, a measureable amount of subsidence often occurs (Gabrysch and Bonnet, 1975).

\section{Data Collection and Analysis Methods}

Water-level data were obtained from observation wells by measuring the depth to water below land surface at each well. Measurements were made by USGS personnel by using calibrated steel tape, airline, or electric water-level tape in accordance with methods described in Cunningham and Schalk (2011). Water-level data also were provided by industrial entities and powerplants operating within the study area that use water for hydrocarbon processing and electrical power generation, respectively. Most of the measured wells were being pumped at least once daily and some more frequently during the period of this study. Well pumps were turned off for at least 1 hour before the waterlevel measurements were made in order to obtain a water-level measurement that approximates the static conditions within the aquifer. Antecedent withdrawal rates and pumping status of nearby wells were not always known, however, and in such instances could have affected the representativeness of the water-level data that were collected. To ensure that the waterlevel measurement recorded was accurate, at least two waterlevel measurements were made at each well while the well was not being pumped. Water-level measurements in wells used to construct sheets 1-14 of this report were collected during December 2014-March 2015 to represent 2015 waterlevel altitudes of the aquifers (tables 1-3; Chicot, Evangeline, and Jasper aquifers, respectively); during December through March, water levels of the aquifers in the Houston-Galveston region are usually higher compared to the rest of the year because rates of groundwater withdrawals during these months generally are at a minimum. In the study area, groundwater levels of the aquifers are generally higher in the late fall, winter, and spring months of the year because of the cooler temperatures, increased precipitation, and an associated decreased groundwater withdrawals. Conversely, groundwater levels of the aquifers decline during the warmer summer months and early fall because of decreased precipitation and increased groundwater withdrawals. Subsequently, after a thorough evaluation, these data were incorporated into a geographic information system (GIS) as point-data layers and used for the construction of sheets 1-14.

\section{Determination of Water-Level Altitudes}

The annual (2015) regional-scale depictions of waterlevel altitudes presented in this report were derived from water-level-measurement data collected during December 2014-March 2015 throughout the 11-county area that includes the greater Houston-Galveston area. The water-level-altitude data used to construct the approximate water-level-altitude maps for the Chicot, Evangeline, and Jasper aquifers (sheets 1,6 , and 11 , respectively) were calculated by subtracting the water-level measurement from the land-surface-altitude value for each point (well). To determine land-surface altitudes, a land-surface datum for each well is obtained from a digital elevation map (DEM), and the elevation of the measuring point is measured by using an engineering ruler. The accuracy of the land-surface-altitude data has gradually improved over the years, and the most accurate land-surface-altitude data available are used by the USGS for each annual depiction of water-level altitudes in the study area. Land-surface altitudes were referenced to the National Geodetic Vertical Datum of 1929 (NGVD 29) or the North American Vertical Datum of 1988 (NAVD 88) (National Oceanic and Atmospheric Administration, 2008) (hereinafter, datum). Although these two datums differ geographically throughout the world, "nowhere in the study area does [the datum difference] exceed more than a couple inches" (Cliff Middleton, National Geodetic Survey, written commun., 2014). The data for each point (well) used for contour configuration on the three approximate 2015 water-level-altitude maps (sheets 1, 6, and 11) are referenced to NAVD 88 (tables 1-3, respectively). These approximate water-level-altitude contours represent 
2015 regional-scale depictions of the water levels in wells in the Chicot, Evangeline, and Jasper aquifers, and the areal extents and locations of these contours represent the combined effects of groundwater withdrawals from all groundwater wells in the study area. Water-level altitudes were depicted by using contour intervals of 25 and $50 \mathrm{ft}$.

\section{Quality Assurance}

Protocols for the collection and review of water-levelaltitude data were followed as described in the USGS Texas Water Science Center internal document "Quality Assurance Plan for Groundwater Activities" (app. 7.3, "Groundwater Data Management Plan" [Greg P. Stanton, U.S. Geological Survey, written commun., 2010]). All data were archived in the USGS National Water Information System (NWIS) (http://waterdata.usgs.gov/tx/nwis/nwis).

The annual (2015) regional-scale depictions of waterlevel altitudes presented in this report were derived from water-level-measurement data collected during December 2014-March 2015 throughout the 11-county area that includes the greater Houston-Galveston area. The water-level altitudes of the Chicot, Evangeline, and Jasper aquifers are continually changing in response to changes in hydrologic conditions, the rates of groundwater withdrawals, and the lack or abundance of precipitation. The water level in wells screened in the Chicot, Evangeline, or Jasper aquifers, therefore, may have declined or risen since the most recent water-level measurements were made. Additionally, the antecedent withdrawal rates and pumping status of nearby wells were not always known and could have affected the representativeness of the water-level data that were used to create the depictions presented in this report.

\section{Depicting Changes in Water-Level Altitudes}

Because the water-level altitudes of the Chicot, Evangeline, and Jasper aquifers are dynamic, the water level in any of the three aquifers may have declined or risen since the most recent water-level measurements were made. The approximate water-level-change contours (sheets 3-5, 8-10, and 13-14) represent regional-scale depictions of water-level change during selected periods for each aquifer. Delineated areas depicting contours of water-level rise or decline represent water-level changes in the aquifers caused by spatial and temporal changes in groundwater withdrawals. Maps depicting changes in water-level altitudes in the Chicot, Evangeline, and Jasper aquifers were constructed for 1-year (2014-15), 5-year (2010-15), and various long-term (1990-2015 [Chicot and Evangeline], 1977-2015 [Chicot and Evangeline], and 2000-15 [Jasper]) periods. To create the various water-level-change maps, datasets of water-levelchange values (difference between the current year [2015] and historical water-level-altitude values) were used. The historical years $(1977,1990$, and 2000) when the water-level-altitude maps were created and published as part of the USGS annual map series are coincident with the creation of the HGSD, FBSD, and LSGCD, respectively.

The magnitudes of water-level changes during 1-year periods often fluctuate because groundwater levels can change appreciably in response to changes in groundwater withdrawals. Additionally, fluctuations in precipitation associated with wet and dry periods appreciably affect the amounts of groundwater withdrawals such that water-level changes during 1-year periods are not representative of longer-term trends. For this reason, the water-level changes for 2014-15 were not contoured but rather depicted as individual point values on sheets 2,7 , and 12 . Whereas the normal annual precipitation for the study area is 52.6 inches (in.), the precipitation total during 2014 was 43.7 in. (National Oceanic and Atmospheric Administration, $2012,2015 b)$. In years with normal amounts of precipitation such as 2008 (Kasmarek and others, 2008, sheets 2, 7, and 12), when a precipitation total of 53.0 in. was recorded (National Oceanic and Atmospheric Administration, 2015b), the spatial distributions of 1-year water-level declines and rises are similar to the spatial distributions of declines and rises depicted on the 1 -year change maps (sheets 2, 7, and 12). Conversely, in years of drought such as 2011, the spatial distributions of 1-year water-level declines and rises mostly consist of water-level declines (Kasmarek and others, 2012, sheets 2, 7, and 12).

For the 1-year (2014-15) water-level-change maps (sheets 2, 7, and 12), water-level changes were computed as the difference between water-level altitude at each point (well) for which a water-level measurement was made in 2014 and in 2015. For the purposes of this report, water-level changes less than $0.49 \mathrm{ft}$ are indicated on the maps as points of no water-level change. Water-level changes on the 1-year maps (sheets 2, 7, and 12) are depicted by using upward-pointing triangles to indicate water-level rises, downward-pointing triangles to indicate water-level declines, and circles to indicate no water-level changes. The number within the water-level rise and decline triangles indicates the amount of water-level change in feet.

For the 5-year (2010-15) water-level-change maps (sheets 3,8 , and 13), water-level changes were computed the same as for the 1-year maps - as the difference between waterlevel altitude at each point (well) for which a water-level measurement was made in 2010 and in 2015. Changes on the 5 -year maps are depicted by contours of equal water-level change. Each 5-year map was constructed by contouring the set of mapped point differences.

For the historical (1977-2015, 1990-2015, and 2000-15) water-level-change maps (sheets 4, 5, 9, 10, and 14), waterlevel changes were computed as the difference between water-level altitude at each point (well) for which a water-level measurement was made in the historical years $(1977,1990$, and 2000) and in 2015. For wells measured in 2015 that had no corresponding measurement in the historical year, a GIS raster (gridded surface) (Worboys, 1995) was created from published historical water-level-altitude contours (1977 [Gabrysch, 1979], 1990 [Barbie and others, 1991; Kasmarek, 1997], and 2000 
[Kasmarek and Houston, 2007]). The maps were constructed by contouring the set of mapped point values computed either as the difference in water-level altitude at each point (well) for which a water-level measurement was made in 2015 and in the historical year or as the difference in water-level altitude at that point in 2015 and the water-level altitude on a gridded surface of the historical year water-level-altitude map (Gabrysch, 1979; Barbie and others, 1991; Kasmarek, 1997; Kasmarek and Houston, 2007) (tables 1-3). Gridded-surface values for the historical year (rather than actual measured values) were used to compute differences (mapped point values) because many of the wells measured in the historical year have been destroyed or were not measured in 2015. For the subset of wells measured both in 2015 and in the historical year, the mapped point values used were the differences in water-level-altitude values between 2015 and the historical year rather than the differences between the 2015 water-levelaltitude values and the historical year gridded-surface values.

\section{Borehole Extensometers}

To construct an extensometer (example shown in fig. 7), a borehole is first drilled to a predetermined depth, generally below the depth of expected water-level decline. A steel outer casing with one or more slip joints and a screened interval is installed in the previously drilled borehole. The slip joint(s) helps to prevent crumpling and collapse of the well casing as compaction of subsurface sediments (hereinafter referred to as "compaction") occurs, and the screened interval allows groundwater to enter the outer casing and inner casing (piezometer, small-diameter well used to measure the water level of an aquifer) so that the depth to water below land surface can be determined for the aquifer at the depth of the screened interval. A substantial cement plug is installed and set at the base of the extensometer, and after the cement plug hardens, the smaller diameter inner pipe (often referred to as the "extensometer pipe") is inserted down hole inside the outer casing and positioned to rest on the upper surface of the cement plug at depth. This rigid inner pipe, therefore, extends vertically from the top of the cement plug to slightly above land surface, thus providing a fixed reference elevation above land surface for measuring changes in land-surface elevation. At land surface, a concrete slab is poured and connected to an array of vertical concrete piers extending down into the water table. The concrete piers connect the slab to the underlying unconsolidated sediments penetrated by the borehole; this construction design helps to eliminate the continuous shrink and swell of the surficial clayey sediments associated with soil-moisture changes. A metal gage house (not depicted in fig. 7) is constructed on the concrete slab, and a shaft encoder and analog recorder are mounted to a steel table that is attached to the concrete slab. A calibrated steel tape connects the recorder to the top of the inner pipe; because the steel table is anchored to the concrete slab, changes in land-surface altitude can be accurately measured and recorded. These recorded values through time represent the cumulative compaction that has occurred at the extensometer site. Because the extensometer functions as a piezometer and an extensometer, the cause and effect relation between the changes in water level in the aquifer and the changes in land-surface elevation can be established. Detailed information on the scientific theory, construction, and operation of extensometers is presented in Gabrysch (1984).

Extensometer data for the 11 sites are used to quantify the rate of compaction in the Chicot and Evangeline aquifers, thereby providing water-resource managers a tool for evaluating the effects on subsidence rates caused by changes in the amount of groundwater withdrawn from the Chicot and Evangeline aquifers. For this report, extensometer data of the cumulative compaction in the Chicot and Evangeline aquifers were collected from and evaluated for 13 extensometers at 11 sites in Harris and Galveston Counties (sheet 15; tables $4 A-4 M$ ).

To quantify the rates of compaction in the aquifers, a network of borehole extensometers was installed beginning in 1973 at selected sites throughout Harris and Galveston Counties. Five extensometers were installed in Harris (four) and Galveston (one) Counties and began recording cumulative compaction data in July 1973: LJ-65-22-622 (East End), LJ-65-16-930 (Baytown C-1 [shallow]), LJ-65-16-931 (Baytown C-2 [deep]), and LJ-65-32-625 (Seabrook) in Harris County and KH-64-33-920 (Texas City-Moses Lake) in Galveston County. An extensometer that had been installed in 1962 in Harris County (LJ-65-32-401 [Johnson Space Center]) was included in the network. Since July 1973, routine measurements of compaction at the Johnson Space Center extensometer have been recorded and collected and are included in this report. Additional extensometers were added to the network during 1974-76 in Harris County: LJ-65-12726 (Addicks) in 1974, LJ-65-23-322 (Pasadena) in 1975, and LJ-65-32-424 (Clear Lake [shallow]) and LJ-65-32-428 (Clear Lake [deep]) in 1976. The final three extensometers in the current (2015) network were installed in Harris County in 1980: LJ-65-07-909 (Lake Houston), LJ-65-14-746 (Northeast), and LJ-65-21-226 (Southwest). Since activation or installation between 1973 and 1980, cumulative compaction data have been constantly recorded and periodically collected about every 28 days at the 13 extensometers on a routine basis, thereby providing site-specific rates of compaction accurate to within $0.001 \mathrm{ft}$ (table 4). Cumulative compaction data discussed in this report end on the last site visit in December 2014.

From late 1973 to late 1982, a noticeable amount of seasonal variation occurred at the two extensometers at the Baytown site. This variation was determined to be caused by the surficial clayey sediments that expand (swell) during periods of precipitation and contract (shrink) during hot and dry periods, which is characteristic of the montmorillonitic clay within the aquifer sediments. Consequently, in 1982, to reduce the excessive recorded fluctuation of the land surface, both extensometers were modified by installing a system of 


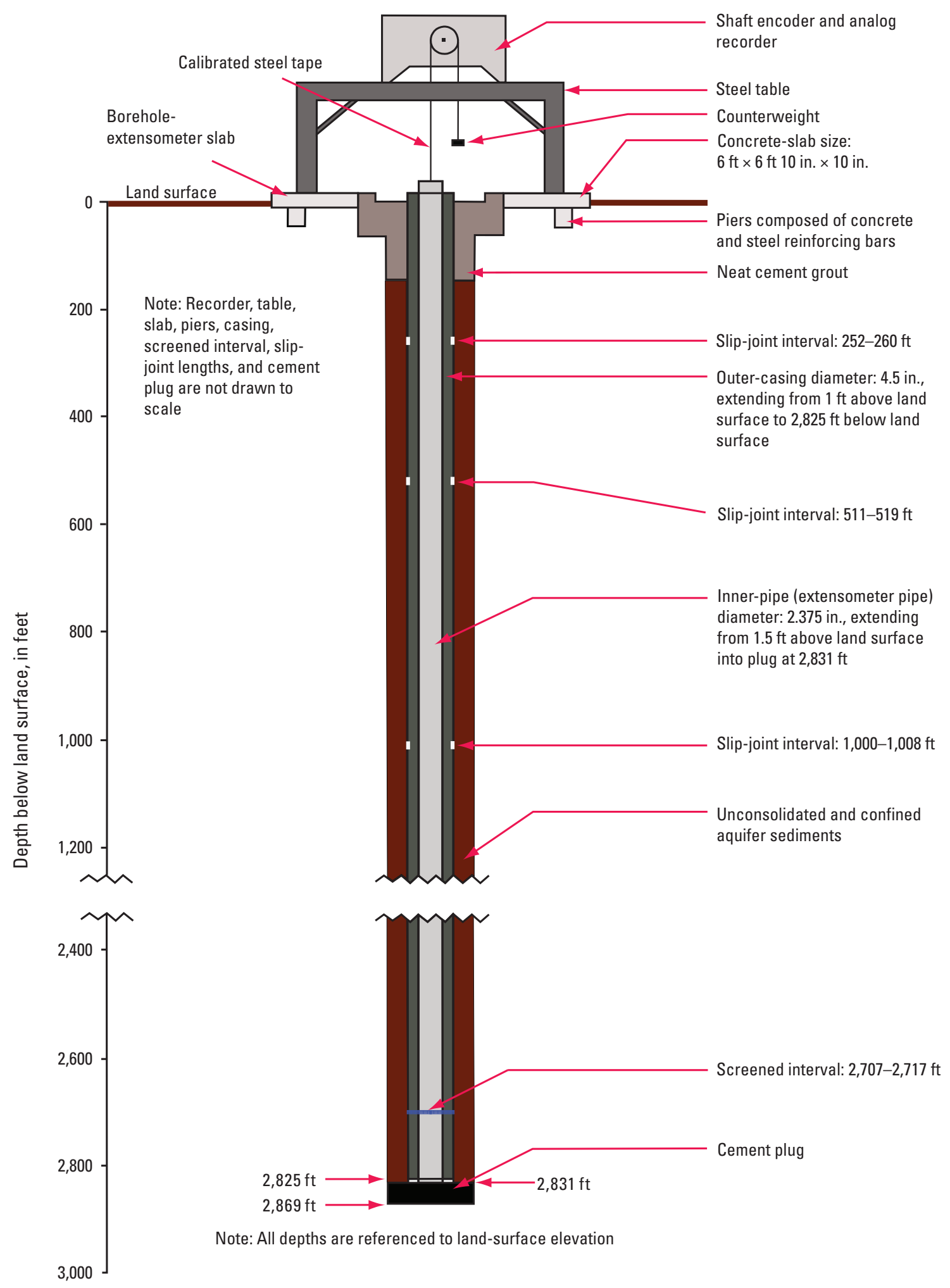

Figure 7. Cross-sectional perspective of the borehole extensometer/piezometer (LJ-65-23-322) located at Pasadena, Texas ( $\mathrm{ft}$, foot; in., inch). 
more deeply penetrating vertical piers into the sediments at the depth of the water table (fig. 7). Data collected after 1982 indicate that these design modifications reduced the fluctuations and improved the accuracy of the data.

Each extensometer has a 10 - to $20-\mathrm{ft}$ screened interval that is located above the cement plug, which allows water to flow into the center pipe and thus functions as a piezometer. A water-level measurement is made during each extensometer site visit. If the depth of the screened interval is positioned entirely within the Chicot aquifer or Evangeline aquifer, these water-level measurements are evaluated to determine if they are representative of water levels in the adjacent area and, when verified, are used in the creation of the waterlevel-altitude maps.

\section{Water-Level Altitudes and Changes}

Locations of wells used to construct the water-levelaltitude maps and water-level-change maps for the Chicot, Evangeline, and Jasper aquifers are shown in appendix 1. The well index numbers on the three maps (apps. 1-1, 1-2, and 1-3) correspond to tabular data (tables 1, 2, and 3, respectively) for each of the water-level-altitude maps or water-level-change maps for each aquifer. The Chicot and Evangeline aquifer maps (sheets 1-5 and 6-10, respectively) depict approximate waterlevel altitudes in 2015 and water-level changes for 2014-15, 2010-15, 1990-2015, and 1977-2015 in these two aquifers. The Jasper aquifer maps (sheets 11-14) depict approximate waterlevel altitudes in 2015 and water-level changes for 2014-15, $2010-15$, and 2000-15. The contoured depictions on the maps showing approximate water-level changes were constructed by using contour intervals relative to the specific range of waterlevel changes for a given map. Adjusting the contour intervals in this way helped to present a clear depiction of regional-scale water-level changes.

\section{Chicot Aquifer}

Water-level measurements from 166 wells (table 1) were used to construct the approximate 2015 water-level-altitude map of the Chicot aquifer (sheet 1). In 2015, the water-level-altitude contours ranged from $175 \mathrm{ft}$ below datum in a localized area in northwestern Harris County to $200 \mathrm{ft}$ above datum in northern and western Montgomery County (sheet 1). In one well (LJ65-20-520) in southwest Harris County near the Harris County and Fort Bend County border, the water-level altitude of $200 \mathrm{ft}$ below datum recorded in 2015 was not contoured because the water-level-altitude value was much greater than water-level altitudes of proximal wells. Depictions of water-level change for 2014-15, 2010-15, 1990-2015, and 1977-2015 are presented on sheets $2,3,4$, and 5 , respectively. The total number of waterlevel-measurement pairs used to construct the water-levelchange maps was 158 for $2014-15,137$ for $2010-15,132$ for 1990-2015, and 121 for 1977-2015 (table 1).
Changes in water-level altitudes in the Chicot aquifer during 2014-15, depicted by numbered upward-pointing triangles to indicate water-level rises, numbered downwardpointing triangles to indicate water-level declines, and circles to indicate no water-level changes, ranged from a $24-\mathrm{ft}$ decline in northern Brazoria County to a 31-ft rise in southwestern Harris County (sheet 2). The 31-ft rise was in well LJ-6520-520 in southwestern Harris County, which is the well that was not contoured for 2015 (sheet 1) because it was not representative of water levels in the area (as explained in the previous paragraph). For 2010-15, contoured changes of water-level altitude ranged from a 40 -ft decline in eastern Fort Bend County and northwestern Brazoria County to a $40-\mathrm{ft}$ rise both in south-central and in north-central Harris County (sheet 3). For 1990-2015, contoured changes in water-level altitude ranged from a $100-\mathrm{ft}$ decline in south-central Montgomery County that extends into a small part of north-central Harris County to a $100-\mathrm{ft}$ rise in southwestern Harris County (sheet 4), excluding the anomalous water-level-change rise of 203 $\mathrm{ft}$ at well LJ-65-21-150 that exceeded all nearby waterlevel-change values by more than $100 \mathrm{ft}$. For 1977-2015, contoured changes in water-level altitude ranged from a $100-\mathrm{ft}$ decline in northwestern Harris County to a $200-\mathrm{ft}$ rise in southeastern Harris County (sheet 5). The 1977-2015 water-level-change map depicts areas of water-level decline in northern, northwestern, and southwestern Harris County and across northern, eastern, and southeastern Fort Bend County into southeastern Waller County (sheet 5). On this same water-level-change map, a broad area of water-level rise is depicted that includes central, eastern, and southeastern Harris County, all of Galveston County, the eastern and northernmost parts of Brazoria County, and part of eastern Fort Bend County (sheet 5).

\section{Evangeline Aquifer}

Water-level measurements from 327 wells (table 2) were used to construct the approximate 2015 water-level-altitude map of the Evangeline aquifer (sheet 6). In 2015, the waterlevel-altitude contours ranged from $250 \mathrm{ft}$ below datum in a localized area extending from south-central Montgomery County into north-central Harris County and in an additional area in central Harris County to $200 \mathrm{ft}$ above datum in southeastern Grimes and northwestern Montgomery Counties (sheet 6). Depictions of water-level change for 2014-15, 2010-15, 1990-2015, and 1977-2015 are presented on sheets $7,8,9$, and 10 , respectively. The total number of water-levelmeasurement pairs used to construct the water-level change maps was 304 for 2014-15, 255 for 2010-15, 251 for 1990 2015, and 251 for 1977-2015 (table 2).

Changes in water-level altitudes in the Evangeline aquifer during 2014-15, depicted by numbered upwardpointing triangles to indicate water-level rises, numbered downward-pointing triangles to indicate water-level declines, and circles to indicate no water-level changes, ranged from a 
66-ft water-level decline in central Harris County to a 78-ft water-level rise in far southwestern Harris County (sheet 7). For 2010-15, contoured changes in water-level altitude ranged from a $60-\mathrm{ft}$ decline in south-central Montgomery County to two small areas of $80-\mathrm{ft}$ rise in far southwestern Harris County (sheet 8). For 1990-2015, contoured changes in water-level altitudes ranged from a $200-\mathrm{ft}$ decline in southcentral Montgomery County and north-central Harris County to a 240 -ft rise in southeastern Harris County (sheet 9). For 1977-2015, contoured changes in water-level altitude ranged from a 320-ft decline in south-central Montgomery County that extends into north-central Harris County to a 240-ft rise in southeastern Harris County (sheet 10). The 1977-2015 water-level-change map depicts a broad area of decline in northern, northwestern, and southwestern Harris County that extends into eastern Waller, southern Montgomery, and western Liberty Counties and into the northeastern and eastern parts of Fort Bend County (sheet 10). A broad area of waterlevel rise was detected in central, eastern, and southeastern Harris County and extending into the northernmost part of Brazoria County and the southwestern part of Liberty County (sheet 10).

\section{Jasper Aquifer}

Water-level measurements from 101 wells (table 3) were used to construct the approximate 2015 water-level-altitude map of the Jasper aquifer (sheet 11). In 2015, the waterlevel-altitude contours ranged from $200 \mathrm{ft}$ below datum in south-central Montgomery County and extending into northcentral Harris County to $250 \mathrm{ft}$ above datum in northwestern Montgomery County (sheet 11). Depictions of water-level change for 2014-15, 2010-15, and 2000-15 are provided on sheets 12,13 , and 14 , respectively. The total number of waterlevel-measurement pairs used to construct the water-level change maps was 93 for 2014-15, 78 for 2010-15, and 85 for 2000-15 (table 3).

Changes in water-level altitudes in the Jasper aquifer during 2014-15, depicted by numbered upward-pointing triangles to indicate water-level rises, numbered downwardpointing triangles to indicate water-level declines, and circles to indicate no water-level changes, ranged from a $17-\mathrm{ft}$ decline in northwestern Montgomery County to a $35-\mathrm{ft}$ rise in south-central Montgomery County (sheet 12). For 2010-15, contoured changes in water-level altitude ranged from a $60-\mathrm{ft}$ decline in north-central Harris County to four small, localized areas of 10-ft rise in north-central Harris County, in western Grimes County, in central San Jacinto County, and near Lake Conroe in western Montgomery County (sheet 13). For 2000-15, the water-level-change map depicts declining water levels throughout most of Montgomery County and in parts of Waller, Grimes, and Harris Counties, ranging from a $220-\mathrm{ft}$ decline in south-central Montgomery County to no change in extreme northwestern Montgomery County (sheet 14).

\section{Compaction of Subsurface Sediments in the Chicot and Evangeline Aquifers}

Compaction of subsurface sediments (mostly in the fine-grained silt and clay layers because little compaction occurs in sand layers) in the Chicot and Evangeline aquifers was recorded continuously by using analog technology at the 13 extensometers at 11 sites (sheet 15) that were either activated or installed between 1973 and 1980. The cumulative compaction data for each extensometer are collected about 13 times per year during site visits. The amount of cumulative compaction for each site visit is determined by subtracting the previously recorded compaction value from the ending compaction value. Graphs of cumulative compaction are presented for 1973 (or later depending on when each extensometer was activated or installed) through December 2014; the rate of compaction varied from site to site (sheet 16). The cumulative compaction data used for the creation of the graphs shown on sheet 16 are listed in tables $4 A-4 M$.

The selected depth of the extensometer (sheet 16) determines the total thickness of sediment over which compaction is measured by the extensometer. Six of the extensometers measure compaction that occurs solely in the Chicot aquifer (East End, Johnson Space Center, Texas CityMoses Lake, Baytown C-1 [shallow], Clear Lake [shallow], and Seabrook), and seven of the extensometers measure compaction that occurs in the Chicot and Evangeline aquifers (Lake Houston, Northeast, Southwest, Addicks, Baytown C-2 [deep], Clear Lake [deep], and Pasadena) (sheet 16).

Prior to the establishment of the HGSD in 1975, the withdrawal of groundwater from the Chicot and Evangeline aquifers was unregulated, and water levels in the aquifers were declining with associated depressuring, dewatering, and compaction (Coplin and Galloway, 1999). By 1977, the withdrawals had resulted in water-level-altitude declines of as much as 300 and $350 \mathrm{ft}$ below datum in the Chicot and Evangeline aquifers, respectively, in southeastern Harris County (Gabrysch, 1979), and correspondingly, by 1979, as much as $10 \mathrm{ft}$ of subsidence had occurred in the HoustonGalveston region (Coplin and Galloway, 1999). A more recent USGS study determined that from the early 1900s until 2001 as much as $12-13 \mathrm{ft}$ of subsidence had occurred in the Pasadena and Baytown areas in Harris County and that most (77-97 percent) of the subsidence in the Houston-Galveston region had occurred prior to the extensometer construction that began in 1973 (Kasmarek, Gabrysch, and Johnson, 2010). The rate of compaction is different at each extensometer site because of the differences in groundwater-withdrawal rates in the adjacent areas of each site and in the ratios of sand, silt, and clay, and the corresponding compressibilities of the subsurface sediments at each site. When reductions in groundwater withdrawals were first mandated following the establishment of the HGSD in 1975 (Harris-Galveston Subsidence District, 2015), the rate of groundwater withdrawal began to gradually decrease in Harris and Galveston Counties, 
and incrementally, a reduction in the rate of compaction was recorded by the extensometers (sheet 16). Coincident with the curtailment of groundwater withdrawals, water levels in the aquifers began to rise and recover (Kasmarek and others, 2014, sheets 5 and 10). The decreases in groundwater withdrawals resulted in water levels rising in the Chicot and Evangeline aquifers as much as $200 \mathrm{ft}$ and $240 \mathrm{ft}$, respectively, as depicted on the two 1977-2015 water-level-change maps (sheets 5 and 10) in the areas encompassing the extensometer sites.

The cumulative compaction data discussed in this report begin on the first site visit in January and end on the last site visit in December for any given year (sheet 16; tables $4 A-4 M$ ). For 2014, cumulative compaction ranged from $0.101 \mathrm{ft}$ (table $4 G$ ) at the Texas City-Moses Lake extensometer that solely measures compaction of the Chicot aquifer to as much as $3.668 \mathrm{ft}$ (table $4 E$ ) at the Addicks extensometer that measures compaction of the Chicot and Evangeline aquifers. The graphs of cumulative compaction data from installation in 1975 through 2014 for the Pasadena extensometer and from installation in 1973 through 2014 for the Baytown C-1 (shallow) and Baytown C-2 (deep) extensometers indicate cumulative compaction values of 0.631 (Pasadena extensometer), 1.051 (Baytown $\mathrm{C}-1$ [shallow] extensometer), and $1.157 \mathrm{ft}$ (Baytown $\mathrm{C}-2$ [deep] extensometer) (sheet 16; tables $4 M, 4 H$, and $4 I$, respectively).

From January through December 2014, the Northeast, Southwest, East End, Addicks, Johnson Space Center, Baytown C-1 (shallow), Baytown C-2 (deep), Seabrook, Clear Lake (deep), and Pasadena extensometers recorded net decreases in land-surface elevation (tables $4 B, 4 C, 4 D, 4 E, 4 F, 4 H, 4 I$, $4 J, 4 L$, and $4 M$, respectively); the Lake Houston and Clear Lake (shallow) extensometers recorded net increases in land-surface elevation (tables $4 A$ and $4 K$, respectively); and the Texas City-Moses Lake extensometer recorded no net change in land-surface elevation (table $4 G$ ). The graphs of cumulative compaction data indicate that the slopes of the graphs and rates of compaction were substantially higher when the extensometers were initially installed as early as 1973 compared to the slopes of the graphs and rates of compaction in the subsequent years (sheet 16). These asymptotic compactionrate patterns are directly related to the rise in water levels in the aquifers as groundwater withdrawals decreased in response to regulatory mandates of the HGSD (Harris-Galveston Subsidence District, 2015). As water levels in the aquifers began to rise and recover, the hydrostatic pressure increased, and excess residual pore pressure equilibrated; hence, the rates of compaction progressively decreased. Coinciding with compaction-rate decreases, the long-term water-level changes for 1990-2015 and 1977-2015 in the Chicot and Evangeline aquifers (sheets $4,5,9$, and 10 , respectively) indicate that, with the exception of the Addicks extensometer site, the locations of these extensometers coincide with the relatively large area of water-level rise.

Cumulative compaction data from the Addicks extensometer (LJ-65-12-726) (table 4E) indicate a consistent rate of compaction beginning from when the extensometer was installed in mid-1974 to about mid-2003; the rate of compaction remained steady during this period because the extensometer is located in area 3 (fig. 1) of the HGSD and, as such, was not scheduled for a 30-percent groundwater reduction until 2010 (Harris-Galveston Subsidence District, 2013). During the period of a consistent rate of compaction from mid-1974 through mid-2003, therefore, groundwater withdrawal continued unabated in the area adjacent to the Addicks extensometer site with an associated calculated rate of compaction of about $0.1 \mathrm{ft}$ per year. Additionally, the rate of compaction during August 2003-December 2003 decreased to about $0.004 \mathrm{ft}$; this decrease in the rate of compaction likely is related to changes in withdrawals, as the adjacent public-supply well field was observed by USGS personnel to be inoperative during this 5 -month period. For December 2003 to about April 2005, data indicate a slight increase in land-surface elevation (rebound), followed by a decrease in land-surface elevation until February 2006. Again in March 2006, a gradual increase in land-surface elevation occurred until March 2008. Compaction resumed (albeit at a lower rate than in 2008) in May 2009, and net decrease in land-surface elevation continued to occur through October 2013. The rate of compaction recorded by the Addicks extensometer averaged about $0.028 \mathrm{ft}$ per year during 2009-14 based on a beginning value of $3.502 \mathrm{ft}$ in January 2009 and an ending value of $3.668 \mathrm{ft}$ in December 2014 (table 4E; sheet 16).

The graph of cumulative compaction data obtained from the Seabrook extensometer (sheet 16) indicates a seasonal sinusoidal pattern in land-surface elevation caused by a decrease in land-surface elevation during the hot and dry months of June through September, when rates of groundwater withdrawals are largest. This decrease in land-surface elevation is followed by an increase in land-surface elevation during the cooler and wetter months of December through March, when rates of withdrawals are lower compared to the rest of year. Additionally, during the hot and dry months of June through September, the surficial clayey sediments desiccate and shrink, but as the heat of the summer dissipates and the cooler and wetter months arrive and groundwater withdrawals decrease, the sediments rehydrate and swell, thereby causing an increase in land-surface elevation, or rebound (U.S. Geological Survey, 2015).

The Baytown C-1 (shallow) and Baytown C-2 (deep) extensometers began recording cumulative compaction data in July 1973 (sheet 16). During about the first 37 years of the period of record through about early May 2009, the cumulative compaction data recorded at the Baytown $\mathrm{C}-1$ (shallow) extensometer were consistently lower than data recorded at the Baytown $\mathrm{C}-2$ (deep) extensometer, with a difference as much as $0.465 \mathrm{ft}$ recorded in July and August 2001. In late May 2009, however, an increase in the rate of compaction recorded at the Baytown $\mathrm{C}-1$ (shallow) extensometer began, and by December 2014, the difference in cumulative compaction data for the two sites was within $0.106 \mathrm{ft}$ (tables $4 H$ and $4 I$ ). What caused this recent increased rate of compaction is not certain, but in addition 
to the factors controlling compaction discussed previously in the section "Subsidence and Compaction Processes," the presence of a known normal fault proximal to the Baytown site documented by Verbeek and Clanton (1978) and Shah and Lanning-Rush (2005) may be a contributing factor. Because of the recent increase in the rate of compaction at the Baytown C-1 (shallow) extensometer, the 2014 trend and difference in cumulative compaction recorded by the Baytown $\mathrm{C}-1$ (shallow) extensometer and the Baytown C-2 (deep) extensometer more closely match the trend and difference in cumulative compaction (0.019 ft in December 2014) recorded by the Clear Lake (shallow) and Clear Lake (deep) extensometers (tables $4 K$ and $4 L$; sheet 16 ).

Cumulative compaction data for the Texas City-Moses Lake extensometer indicate not only that a halt in the rate of compaction occurred but also, since January 1981, a slight land-surface-elevation rise of approximately $0.092 \mathrm{ft}$ occurred (table $4 G$; sheet 16). The graphs of cumulative compaction data for the Pasadena, Clear Lake (shallow), Clear Lake (deep), Seabrook, Baytown C-1 (shallow), Baytown C-2 (deep), and Johnson Space Center extensometers indicate a slight increase in land-surface elevation from late 1978 to early 1980 because a ruptured natural gas well pressurized the confined aquifer system and caused water levels to rise in the area adjacent to the ruptured well (Gabrysch, 1984). Gradually, the pressure in the aquifer dissipated, and the process of compaction subsequently returned to similar rates that existed prior to the pressuring event.

The graphs of cumulative compaction data for the two Baytown extensometers (Baytown C-1 [shallow] and Baytown $\mathrm{C}-2$ [deep]) indicate a noticeable amount of seasonal variation from late 1973 to late 1982, which was determined to be caused by the contracting and expanding (shrinking and swelling) characteristics of the montmorillonitic clay within the aquifer sediments. To address the problem of shrinking and swelling of surficial clayey sediments at these extensometer sites, in 1982, a modification was made to the original design of the extensometers by installing a system of vertical piers that are anchored to the concrete slabs of the extensometers and extend downward to the depth of the water table (fig. 7). By comparing the cumulative compaction graphs from before and after 1982, it can be seen that these design modifications improved the accuracy of the data.

\section{Data Limitations}

Most land-surface elevations at wells used during this study were derived from USGS 1:24,000-scale 7.5-minute topographic quadrangle maps and are accurate to plus or minus $2.5 \mathrm{ft}$. Land-surface altitudes at wells installed in Harris County were derived from a DEM from the 2001 Tropical Storm Allison Recovery Project land-surface dataset that used light detection and ranging (lidar) technology (Peggy Cobb, Terrapoint USA, Inc., written commun., 2009). These altitudes are referenced to NAVD 88 by using Corpscon version 6
(U.S. Army Corps of Engineers, 2006). The lidar data were contoured at a $1-\mathrm{ft}$ interval, thereby providing $0.5-\mathrm{ft}$ accuracy. The topographic quadrangle maps for the Gulf Coast area were typically contoured at a 5 -ft interval, thereby providing $2.5-\mathrm{ft}$ accuracy; thus, the lidar data provide about five times better accuracy when compared to topographic quadrangle maps (Kasmarek, Gabrysch, and Johnson, 2010). In addition, all of the topographic quadrangle maps are variously dated and have not been updated with changes in land-surface altitude that might have occurred since their initial publication. Changes in land-surface altitudes were not included in the analysis of differences between current year and previous year water-levelaltitude maps. The effects of land-surface-altitude changes on water-level-change maps need to be accounted for if the change maps are to accurately reflect differences between current year and previous year water-level-altitude maps (for each of which, the best available land-surface altitudes at well locations at the time that the maps were constructed were used).

The depictions of water-level altitudes and changes at any specific location are considered to represent a regionalscale approximation and, as such, are not intended for use in engineering or other design applications. The water-level altitudes and changes presented in this report were rounded to the nearest foot; the values depicted on the maps represent a mathematical approximation that could vary as much as plus or minus $0.5 \mathrm{ft}$ in addition to accuracies associated with the source data. Use of these data for critical or local-scale applications is not advised without full awareness of the data limitations. Users need to exercise discretion when drawing conclusions or making policy decisions on the basis of these contoured depictions.

Cumulative compaction data recorded at each extensometer site (sheet 16) indicate the measured compaction for subsurface sediments above the depth of the cement plug (fig. 7); any compaction or vertical movement that occurs below these depths is not measured by the extensometers. Depending on the total depth of the extensometer, the compaction at a given extensometer could represent solely the sediments of the Chicot aquifer (for example, the Baytown $\mathrm{C}-1$ [shallow] extensometer) or could represent the sediments for both the Chicot and Evangeline aquifers (for example, the Addicks extensometer).

Because rates of nearby groundwater withdrawals and ratios of sand, silt, and clay and compressibilities vary from site to site, the rate of compaction varies from site to site (sheet 16). It is not appropriate, therefore, to extrapolate or infer a rate of compaction for an adjacent area on the basis of the rate of compaction measured at proximal extensometers.

\section{Summary}

The Houston-Galveston region, Texas - consisting of Harris, Galveston, Fort Bend, Montgomery, Brazoria, Chambers, Grimes, Liberty, San Jacinto, Walker, and Waller Counties - represents one of the largest areas of land-surface subsidence (hereafter, subsidence) in the United States. By 
1979, as much as 10 feet (ft) of subsidence had occurred in the Houston-Galveston region, and approximately 3,200 square miles $\left(\mathrm{mi}^{2}\right)$ of the 11,000- $\mathrm{mi}^{2}$ geographic area had subsided more than $1 \mathrm{ft}$. Most of the subsidence in the Houston-Galveston region has occurred as a direct result of groundwater withdrawals that depressured and dewatered the Chicot and Evangeline aquifers, thereby causing compaction of the aquifer sediments. Groundwater withdrawn from the Chicot, Evangeline, and Jasper aquifers has been the primary source of water for municipal supply, commercial and industrial use, and irrigation in the Houston-Galveston region since the early 1900s. To address the issues associated with subsidence and subsequent increased flooding, the 64th Texas State Legislature in 1975 authorized the establishment of the Harris-Galveston Subsidence District to regulate and reduce groundwater withdrawals in Harris and Galveston Counties. Subsequently, the Texas State Legislature established the Fort Bend Subsidence District in 1989 and the Lone Star Groundwater Conservation District in 2001 to regulate groundwater withdrawals in Fort Bend and Montgomery Counties, respectively. The Brazoria County Groundwater Conservation District was established by the Texas State Legislature in 2003 with the purpose to maintain the quality and availability of the county's groundwater resources for current users and future generations. This report, prepared by the U.S. Geological Survey in cooperation with the HarrisGalveston Subsidence District, City of Houston, Fort Bend Subsidence District, Lone Star Groundwater Conservation District, and Brazoria County Groundwater Conservation District, is one in an annual series of reports depicting water-level altitudes and water-level changes in the Chicot, Evangeline, and Jasper aquifers and measured cumulative compaction of subsurface sediments in the Chicot and Evangeline aquifers in the Houston-Galveston region. Water levels in wells screened in the Chicot, Evangeline, and Jasper aquifers were measured during December 2014-March 2015 (water levels usually are higher during these months compared to the rest of the year).

This report contains regional-scale maps depicting approximate 2015 water-level altitudes for the Chicot, Evangeline, and Jasper aquifers; maps depicting 1-year (201415) water-level changes for each aquifer; maps depicting approximate contoured 5-year (2010-15) water-level changes for each aquifer; maps depicting approximate contoured longterm (1990-2015 and 1977-2015) water-level changes for the Chicot and Evangeline aquifers; a map depicting approximate contoured long-term (2000-15) water-level changes for the Jasper aquifer; a map depicting locations of boreholeextensometer (hereinafter referred to as "extensometer") sites; and graphs depicting cumulative compaction of subsurface sediments measured by the extensometers beginning in 1973 (or later depending on when the extensometer was activated or installed) through December 2014. Tables listing the data used to construct each water-level map for each aquifer and the measured cumulative compaction graphs are included.
Water-level measurements from 166 wells were used to construct the approximate 2015 water-level-altitude map of the Chicot aquifer, and contours of the approximate 2015 waterlevel altitudes in this aquifer ranged from $175 \mathrm{ft}$ below the vertical datum (the National Geodetic Vertical Datum of 1929 or the North American Vertical Datum of 1988; hereinafter, datum) in a localized area in northwestern Harris County to $200 \mathrm{ft}$ above datum in northern and western Montgomery County. Water-level changes in the Chicot aquifer for 2014-15 ranged from a 24-ft decline in northern Brazoria County to a 31-ft rise in southwestern Harris County. Contoured 5-year and long-term water-level changes in the Chicot aquifer ranged from a 40-ft decline to a 40-ft rise (2010-15), from a 100 -ft decline to a 100-ft rise (1990-2015), and from a 100-ft decline to a 200-ft rise (1977-2015). The 1977-2015 waterlevel-change map for this aquifer depicts areas of water-level decline in northern, northwestern, and southwestern Harris County and across northern, eastern, and southeastern Fort Bend County into southeastern Waller County. Depictions also indicate a broad area of water-level rise in central, eastern, and southeastern Harris County, all of Galveston County, the eastern and northernmost parts of Brazoria County, and part of eastern Fort Bend County.

Water-level measurements from 327 wells were used to construct the approximate 2015 water-level-altitude map of the Evangeline aquifer. Contours of the approximate 2015 waterlevel altitudes in this aquifer ranged from $250 \mathrm{ft}$ below datum in a localized area extending from south-central Montgomery County into north-central Harris County and in an additional area in central Harris County to $200 \mathrm{ft}$ above datum in southeastern Grimes and northwestern Montgomery Counties. Water-level changes for 2014-15 ranged from a 66-ft decline to a 78 -ft rise. For 2010-15, the contoured changes in waterlevel altitudes ranged from a $60-\mathrm{ft}$ decline to an $80-\mathrm{ft}$ rise. For 1990-2015, contoured changes in water-level altitudes ranged from a 200-ft decline to a 240-ft rise, and for 1977-2015, contoured changes in water-level altitudes ranged from a $320-\mathrm{ft}$ decline to a $240-\mathrm{ft}$ rise. The $1977-2015$ water-levelchange map for this aquifer indicate a broad area of decline in northern, northwestern, and southwestern Harris County that extends into eastern Waller, southern Montgomery, and western Liberty Counties and into the northeastern and eastern parts of Fort Bend County. A broad area of water-level rise was detected in central, eastern, and southeastern Harris County and extending into the northernmost part of Brazoria County and the southwestern part of Liberty County.

Water-level measurements from 101 wells were used to construct the approximate 2015 water-level-altitude map of the Jasper aquifer, and contours of the approximate 2015 water-level altitudes in the this aquifer ranged from $200 \mathrm{ft}$ below datum in south-central Montgomery County northcentral Harris County to $250 \mathrm{ft}$ above datum in northwestern Montgomery County. Water-level-altitude changes in the Jasper aquifer for 2014-15 ranged from a 17-ft decline to a 35 -ft rise. For 2010-15, contoured changes in water-level altitudes in the Jasper aquifer ranged from a $60-\mathrm{ft}$ decline to 
four, small localized areas of 10 -ft rise. The $2000-15$ waterlevel-change maps for this aquifer depict that water-level altitudes declined throughout most of Montgomery County and in parts of Waller, Grimes, and Harris Counties, ranging from a 220 -ft decline in south-central Montgomery County to no change in extreme northwestern Montgomery County.

Compaction of subsurface sediments (mostly in the fine-grained silt and clay layers) in the Chicot and Evangeline aquifers was recorded continuously at the 13 borehole extensometers at 11 sites since the extensometers were either activated or installed between 1973 and 1980. The compaction rates measured by each extensometer were substantially higher when the extensometers were initially installed compared to compaction rates in subsequent years. When reductions in groundwater withdrawals were mandated following the establishment of the Harris-Galveston Subsidence District in 1975 , the rate of groundwater withdrawal began to gradually decrease in Harris and Galveston Counties, as did the rate of compaction. Coincident with the curtailment of groundwater withdrawals, the water levels in the aquifers began to rise and recover. Water levels in the Chicot and Evangeline aquifers have risen as much as 200 and $240 \mathrm{ft}$, respectively, as depicted on the two long-term (1977-2015) water-level-change maps in the areas encompassing the extensometer sites. For the period of record beginning in 1973 (or later depending on activation or installation date) and ending in December 2014, measured cumulative compaction at the 13 extensometers in the Chicot and Evangeline aquifers ranged from $0.101 \mathrm{ft}$ at the Texas City-Moses Lake extensometer that measures compaction solely in the Chicot aquifer to $3.668 \mathrm{ft}$ at the Addicks extensometer that measures compaction of the Chicot and Evangeline aquifers.

During 2014, a total of 10 of the 13 extensometers recorded a slight net decrease of land-surface elevation; the extensometers at the Lake Houston and the Clear Lake (shallow) sites recorded a slight net increase of land-surface elevation, and the extensometer at the Texas City-Moses Lake site recorded no change in elevation.

Because rates of nearby groundwater withdrawals and ratios of sand, silt, and clay and compressibilities vary from site to site, the rate of compaction varies from site to site. It is not appropriate, therefore, to extrapolate or infer a rate of compaction for an adjacent area on the basis of the rate of measured compaction at proximal extensometers.

\section{References Cited}

Allen, A.S., 1969, Geologic settings of subsidence, in Varnes, D.J., and Kiersch, George, eds., Reviews in engineering geology: Geological Society of America, v. 2, p. 305-342.

Baker, E.T., Jr., 1979, Stratigraphic and hydrogeologic framework of part of the Coastal Plain of Texas: Texas Department of Water Resources Report 236, 43 p.
Baker, E.T., Jr., 1986, Hydrology of the Jasper aquifer in the southeast Texas Coastal Plain: Texas Water Development Board Report 295, 64 p.

Barbie, D.L., Coplin, L.S., and Locke, G.L., 1991, Approximate altitude of water levels in wells in the Chicot and Evangeline aquifers in the Houston area, Texas, January-February 1990: U.S. Geological Survey Open-File Report 91-240, 2 sheets, accessed January 27, 2015, at http://pubs.er.usgs.gov/ publication/ofr91240.

Brazoria County Groundwater Conservation District, 2012, Brazoria County Groundwater Conservation District groundwater management plan: Brazoria County Groundwater Conservation District, 76 p., accessed February 14, 2015, at http://www.bcgroundwater.org/images/ bcg/documents/BCGCD_Groundwater_Management_ Plan_20121213.pdf.

Carr, J.E., Meyer, W.R., Sandeen, W.M., and McLane, I.R., 1985, Digital models for simulation of ground-water hydrology of the Chicot and Evangeline aquifers along the Gulf Coast of Texas: Texas Department of Water Resources Report 289, $101 \mathrm{p}$.

Chowdhury, A.H., and Turco, M.J., 2006, Geology of the Gulf Coast aquifer, Texas, chap. 2 of Mace, R.E., Davidson, S.C., Angle, E.S., and Mullican, W.F., eds., Aquifers of the Gulf Coast of Texas: Texas Water Development Board Report 365, p. 23-50.

Coplin, L.S., 2001, Water-level altitudes in wells completed in the Jasper aquifer, greater Houston area, Texas, spring 2000: U.S. Geological Survey Open-File Report 01-147, 2 p., accessed April 13, 2015, at http://pubs.usgs.gov/of/2001/ ofr01-147/.

Coplin, L.S., and Galloway, Devin, 1999, Houston-Galveston, Texas-Managing coastal subsidence, in Galloway, Devin, Jones, D.R., and Ingebritsen, S.E., eds., Land subsidence in the United States: U.S. Geological Survey Circular 1182, p. 35-48.

Cunningham, W.L., and Schalk, C.W., comps., 2011, Groundwater technical procedures of the U.S. Geological Survey: U.S. Geological Survey Techniques and Methods 1A1, 151 p., accessed March 15, 2013, at http://pubs.usgs.gov/ $\mathrm{tm} / 1 \mathrm{a} 1 /$.

Federal Geographic Data Committee, 2015, Geospatial metadata standards: Federal Geographic Data Committee, accessed August 29, 2015, at http://www.fgdc.gov/metadata/ geospatial-metadata-standards. 
Fort Bend Subsidence District, 2013, Fort Bend Subsidence District 2003 regulatory plan [amended 2007, 2009, and 2013]: Fort Bend Subsidence District, 15 p., accessed February 14, 2013, at http://www.fbsubsidence.org/ docs_reports/2013/2003\%20Regulatory $\% 20$ Plan $\% 20$ Amended\%20August\%2028,\%202013.pdf.

Freeze, R.A., and Cherry, J.A., 1979, Groundwater: Englewood Cliffs, N.J., Prentice-Hall, 604 p.

Gabrysch, R.K., 1979, Approximate altitude of water levels in wells in the Chicot and Evangeline aquifers in the Houston area, Texas, spring 1977 and spring 1978: U.S. Geological Survey Open-File Report 79-334, 4 sheets.

Gabrysch, R.K., 1984, Ground-water withdrawals and landsurface subsidence in the Houston-Galveston region, Texas, 1906-80: Texas Department of Water Resources Report 287,64 p.

Gabrysch, R.K., and Bonnet, C.W., 1975, Land-surface subsidence in the Houston-Galveston region, Texas: Texas Water Development Board Report 188, 19 p.

Gabrysch, R.K., and Ranzau, C.E., 1981, Approximate water-level changes in wells in the Chicot and Evangeline aquifers, 1977-81 and 1980-81, and measured compaction, 1973-81, in the Houston-Galveston region, Texas: U.S. Geological Survey Open-File Report 81-341.

Galloway, Devin, Jones, D.R., and Ingebritsen, S.E., eds., 1999, Land subsidence in the United States: U.S. Geological Survey Circular 1182, 177 p.

Harris-Galveston Subsidence District, 2013, Regulatory plan 2013: Harris-Galveston Subsidence District, 14 p., accessed July 4, 2015, at http://hgsubsidence.org/wp-content/ uploads/2013/07/HGSD-2013-Regulatory-Plan-withAmendment.pdf.

Harris-Galveston Subsidence District, 2015, District enabling act: Harris-Galveston Subsidence District, accessed July 4, 2015, at http://hgsubsidence.org/?s=enabling+act.

Holzer, T.L., and Bluntzer, R.L., 1984, Land subsidence near oil and gas fields, Houston, Texas: Ground Water, v. 22, p. $450-459$.

Johnson, M.R., Ramage, J.K., and Kasmarek, M.C., 2011, Water-level altitudes 2011 and water-level changes in the Chicot, Evangeline, and Jasper aquifers and compaction 1973-2010 in the Chicot and Evangeline aquifers, Houston-Galveston region, Texas: U.S. Geological Survey Scientific Investigations Map 3174, 17 p., 16 sheets.
Kasmarek, M.C., 1997, Water-level altitudes in wells completed in the Chicot and Evangeline aquifers, Fort Bend County and adjacent areas, Texas, January-March 1990: U.S. Geological Survey Open-File Report 97-784, 2 sheets, accessed January 29, 2015, at http://pubs.usgs.gov/ of/1997/0784/.

Kasmarek, M.C., 2013, Hydrogeology and simulation of groundwater flow and land-surface subsidence in the northern part of the Gulf Coast aquifer system, Texas, 1891-2009 (ver. 1.1, December 2013): U.S. Geological Survey Scientific Investigations Report 2012-5154, 55 p. [Also available at http://pubs.usgs.gov/sir/2012/5154/.]

Kasmarek, M.C., Gabrysch, R.K., and Johnson, M.R., 2010, Estimated land-surface subsidence in Harris, Texas, 1915-17 to 2001: U.S. Geological Survey Scientific Investigations Map 3097, 2 sheets.

Kasmarek, M.C., and Houston, N.A., 2007, Water-level altitudes 2007 and water-level changes in the Chicot, Evangeline, and Jasper aquifers and compaction 19732006 in the Chicot and Evangeline aquifers, HoustonGalveston region, Texas: U.S. Geological Survey Scientific Investigations Map 2968, 159 p., 18 sheets.

Kasmarek, M.C., and Houston, N.A., 2008, Water-level altitudes 2008 and water-level changes in the Chicot, Evangeline, and Jasper aquifers and compaction 19732007 in the Chicot and Evangeline aquifers, HoustonGalveston region, Texas: U.S. Geological Survey Scientific Investigations Map 3031, 4 p., 17 sheets.

Kasmarek, M.C., Houston, N.A., and Brown, D.W., 2006, Water-level altitudes 2006 and water-level changes in the Chicot, Evangeline, and Jasper aquifers and compaction 1973-2005 in the Chicot and Evangeline aquifers, HoustonGalveston region, Texas: U.S. Geological Survey Open-File Report 2006-1079, 15 sheets.

Kasmarek, M.C., Houston, N.A., and Ramage, J.K., 2009, Water-level altitudes 2009 and water-level changes in the Chicot, Evangeline, and Jasper aquifers and compaction 1973-2008 in the Chicot and Evangeline aquifers, HoustonGalveston region, Texas: U.S. Geological Survey Scientific Investigations Map 3081, 3 p., 16 sheets, 2 apps. [Revised August 11, 2009.]

Kasmarek, M.C., Johnson, M.R., and Ramage, J.K., 2010, Water-level altitudes 2010 and water-level changes in the Chicot, Evangeline, and Jasper aquifers and compaction 1973-2009 in the Chicot and Evangeline aquifers, HoustonGalveston region, Texas: U.S. Geological Survey Scientific Investigations Map 3138, 17 p., 16 sheets, 1 app. 
Kasmarek, M.C., Johnson, M.R., and Ramage, J.K., 2012, Water-level altitudes 2012 and water-level changes in the Chicot, Evangeline, and Jasper aquifers and compaction 1973-2011 in the Chicot and Evangeline aquifers, HoustonGalveston region, Texas: U.S. Geological Survey Scientific Investigations Map 3230, 18 p., 16 sheets.

Kasmarek, M.C., Johnson, M.R., and Ramage, J.K., 2013, Water-level altitudes 2013 and water-level changes in the Chicot, Evangeline, and Jasper aquifers and compaction 1973-2012 in the Chicot and Evangeline aquifers, HoustonGalveston region, Texas: U.S. Geological Survey Scientific Investigations Map 3263, 19 p., 16 sheets.

Kasmarek, M.C., Johnson, M.R., and Ramage, J.K., 2014, Water-level altitudes 2014 and water-level changes in the Chicot, Evangeline, and Jasper aquifers and compaction 1973-2013 in the Chicot and Evangeline aquifers, HoustonGalveston region, Texas: U.S. Geological Survey Scientific Investigations Map 3308, 20 p., 16 sheets.

Kasmarek, M.C., and Lanning-Rush, Jennifer, 2004, Waterlevel altitudes 2004 and water-level changes in the Chicot, Evangeline, and Jasper aquifers and compaction 1973-2003 in the Chicot and Evangeline aquifers, Houston-Galveston region, Texas: U.S. Geological Survey Open-File Report 2004-1084, 13 sheets.

Kasmarek, M.C., and Robinson, J.L., 2004, Hydrogeology and simulation of ground-water flow and land-surface subsidence in the northern part of the Gulf Coast aquifer system, Texas: U.S. Geological Survey Scientific Investigations Report 2004-5102, 111 p.

Lambeck, Kurt, Esat, T.M., and Potter, Emma-Kate, 2002, Links between climate and sea levels for the past three million years: Nature, v. 419, no. 6903, p. 199-206, accessed February 14, 2015, at http://www.nature.com/ nature/journal/v419/n6903/full/nature01089.html.

Lone Star Groundwater Conservation District, 2013, District regulatory plan phase II (B): Lone Star Groundwater Conservation District, accessed February 14, 2015, at http:// www.lonestargcd.org/wp-content/uploads/2012/10/CleanFinal-Revisions-to-DRP-Phase-IIB-11-12-13.pdf.

Meyer, W.R., and Carr, J.E., 1979, A digital model for simulation of ground-water hydrology in the Houston area, Texas: Texas Department of Water Resources LP-103, 27 p.

National Oceanic and Atmospheric Administration, 2008, The elements of geodesy_-The vertical datum: National Oceanic and Atmospheric Administration, accessed February 14, 2015, at http://oceanservice.noaa.gov/education/kits/ geodesy/geo06_vertdatum.html.
National Oceanic and Atmospheric Administration, 2012, Comparative climatic data for the United States through 2012: National Oceanic and Atmospheric Administration, accessed April 14, 2014, at http://www1.ncdc.noaa.gov/pub/ data/ccd-data/CCD-2012.pdf.

National Oceanic and Atmospheric Administration, 2015a, National Hurricane Center-Storm surge overview: National Oceanic and Atmospheric Administration, accessed February 24, 2015, at http://www.nhc.noaa.gov/ surge/.

National Oceanic and Atmospheric Administration, 2015b, National Weather Service Weather Forecast OfficeHouston/Galveston, TX: National Oceanic and Atmospheric Administration, accessed July 11, 2015, at http://www.srh. noaa.gov/hgx/?n=climate_iah_normals_summary.

National Weather Service, 2001, Service assessmentTropical Storm Allison heavy rains and floods Texas and Louisiana June 2001: Silver Spring, Md., Department of Commerce, National Oceanic and Atmospheric Administration, National Weather Service, 31 p., 3 apps., accessed February 14, 2015, at http://www.nws.noaa.gov/ os/assessments/pdfs/allison.pdf.

Peter, G.C., Mace, R.E., and Petrossian, Rima, 2011, Aquifers of Texas: Texas Water Development Board Report 380, 172 p.

Popkin, B.P., 1971, Ground-water resources of Montgomery County, Texas: Texas Water Development Board Report $136,143 \mathrm{p}$.

Pratt, W.E., and Johnson, D.W., 1926, Local subsidence of the Goose Creek oil field (Texas): Journal of Geology, v. 34, no. 7, p. 577-590.

Sellards, E.H., Adkins, W.S., and Plummer, F.B., 1932, The geology of Texas, volume 1-Stratigraphy: The University of Texas Bulletin 3232, 1,007 p.

Shah, S.D., and Lanning-Rush, Jennifer, 2005, Principal faults in the Houston, Texas, metropolitan area: U.S. Geological Survey Scientific Investigations Map 2874, 1 pl.

Strom, E.W., Houston, N.A., and Garcia, C.A., 2003a, Selected hydrogeologic datasets for the Chicot aquifer, Texas: U.S. Geological Survey Open-File Report 03-297, 1 CD-ROM.

Strom, E.W., Houston, N.A., and Garcia, C.A., 2003b, Selected hydrogeologic datasets for the Evangeline aquifer, Texas: U.S. Geological Survey Open-File Report 03-298, 1 CD-ROM.

Strom, E.W., Houston, N.A., and Garcia, C.A., 2003c, Selected hydrogeologic datasets for the Jasper aquifer, Texas: U.S. Geological Survey Open-File Report 03-299, 1 CD-ROM. 
Trahan, D.B., 1982, Monitoring local subsidence in areas of potential geopressured fluid withdrawal, southwestern Louisiana: Gulf Coast Association of Geological Societies Transactions, v. 32, p. 231-236.

University of Texas, Bureau of Economic Geology, 1968, Geologic atlas of Texas, Beaumont sheet: Austin, University of Texas, Bureau of Economic Geology, scale 1:250,000.

University of Texas, Bureau of Economic Geology, 1974, Geologic atlas of Texas, Austin sheet: Austin, University of Texas, Bureau of Economic Geology, scale 1:250,000.

U.S. Army Corps of Engineers, 2006, Corpscon version 6: Topographic Engineering Center, Survey Engineering and Mapping Center of Expertise, accessed February 14, 2015, at http://www.agc.army.mil/Missions/Corpscon.aspx.

U.S. Geological Survey, 2015, Environmental characteristics of clays and clay mineral deposits: U.S. Geological Survey, accessed April 16, 2015, at http://pubs.usgs.gov/info/clays/.

Verbeek, E.R., and Clanton, U.S., 1978, Map showing surface faults in southeastern Houston metropolitan area, Texas: U.S. Geological Survey Open-File Report 78-797, 20 p.

Wesselman, J.B., 1972, Ground-water resources of Fort Bend County, Texas: Texas Water Development Board Report $155,176 \mathrm{p}$.

Winslow, A.G., and Doyel, W.W., 1954, Land-surface subsidence and its relation to the withdrawal of ground water in the Houston-Galveston region, Texas: Economic Geology, v. 40, no. 4, p. 413-422, accessed February 14, 2015, at http://econgeol.geoscienceworld.org/ content/49/4/413.full.pdf + html.

Winslow, A.G., and Wood, L.A., 1959, Relation of land subsidence to ground-water withdrawals in the upper Gulf Coast region, Texas: Mining Engineer, v. 11, no. 10, p. 1030-1034.

Worboys, M.F., 1995, GIS-A computer science perspective: London, Taylor and Francis, 376 p. 

